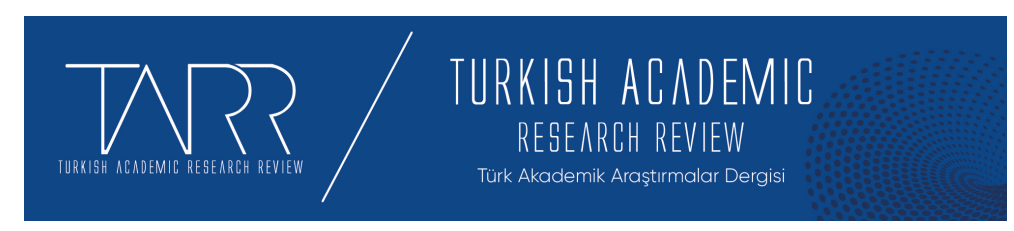

e-ISSN: 2602-2923

Yıl/Year: 2020 Cilt/Volume: 5 Sayı/Issue: 4

\title{
Mevlânâ'nın Mesnevî'sinde Köpek Metaforu
}

The Metaphor of Dog in Mawlana's Masnawî

\section{Ömer Dilmen}

Dr., MEB, omerdilmen@hotmail.com, Orcid ID: 0000-0001-7671-2571

\begin{tabular}{r|l} 
Makale Bilgisi & Article Information \\
Makale Türü - Article Type & Araştırma Makalesi / Research Article \\
Geliş Tarihi - Date Received & 31 Ekim / October 2020 \\
Kabul Tarihi - Date Accepted & 26 Aralık / December 2020 \\
Yayın Tarihi - Date Published & 30 Aralık / December 2020 \\
Yayın Sezonu & Ekim - Kasım - Aralık \\
Pub Date Season & October - November - December
\end{tabular}

Atıf / Cite as: Dilmen, Ömer, Mevlânâ'nın Mesnevî̀sinde Köpek Metaforu/The Metaphor of Dog in Mawlana's Masnawî. tarr: Turkish Academic Research Review, 5 (4), 507-535. doi: 10.30622 tarr.819021.

Intihal / Plagiarism: Bu makale, en az iki hakem tarafından incelenmiş ve intihal içermediği teyit edilmiştir. / This article has been reviewed by at least two referees and confirmed to include no plagiarism. https://dergipark.org.tr/tr/pub/tarr

Copyright (C) Published by Mehmet ŞAHIN Since 2016- Akdeniz University, Faculty of Theology, Antalya, 07058 Turkey. All rights reserved.

Turkish Academic Research Review - Türk Akademik Araştırmalar Dergisi https://dergipark.org.tr/tr/pub/tarr 


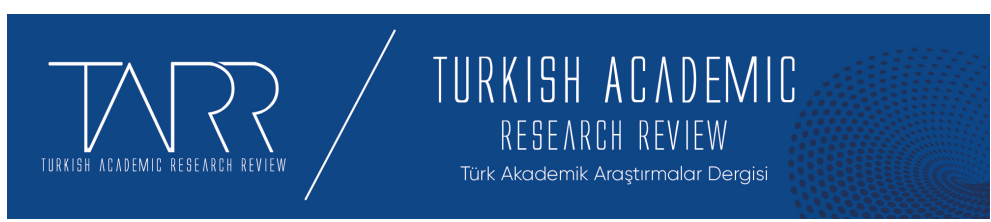

e-ISSN: 2602-2923

Yıl/Year: 2020

Cilt/Volume: 5

Sayı/Issue: 4

\title{
Mevlânâ'nın Mesnevî'sinde Köpek Metaforu
}

\section{Ömer Dilmen}

\section{Özet}

Dünya edebiyatında hayvan hikâyeleri ile insanların hayatlarına dair esasların anlatılması M. Ö. VI. yüzyıla dayandırılır. Bu hayvan hikâyeleri ile siyaset, ahlak, tasavvuf gibi insanı ilgilendiren temel konulara temas edilmiştir. Hakîkatlerin hayvanlar üzerinden anlatım tarzı pek çok medeniyette yaygınlık kazanmış bir husustur. Müslüman dünyasında Mevlânâ, Mesnevî'sinde kullandığı hayvan karakterleri ile dikkat çekmiştir. Mevlânâ, Mesnevî̀sinde kullandığı hayvan hikâyeleri ile somut konulardan hareketle soyut konuların anlaşılmasını sağlamıştır. Biz bu çalışmamızda Mevlânâ'nın Mesnevî̀'sinde köpeğe yüklediği metaforik anlamları ele aldık. Tasavvuf kültüründe genellikle "nefsine uyarak dünyalık peşinde koşan, hakîkatten habersiz câhil kişi" şeklinde değerlendirilen köpek, Mesnevî̀ de "bâtıl inanç, zâlim, kötülük, dünyaya düşkünlük, ruh-beden farklılığı, şeytan, nefs, nefse uymak, arzu ve istekler, câhillik, câhillerden yüz çevirmek, kâfir, münâfıklık, iki yüzlülük, hayâsızlık, tevekkülsüzlük, sahte mürşidler, gazaplanmak, aşktan yoksunluk” gibi olumsuz; “Allah'a itaat, Mevlâ'yı aramak, sırra mazhar olmak, vefâ, aşk, Hak âşı̆̆ı, Allah dostu, düşünmek, akletmek” gibi olumlu metaforik anlamlarda kullanmıştır. Bu çalışmada hedeflenen Mevlânâ'nın insana dair hakîkatleri anlatırken köpek karakteri üzerinden kullandığı incelikli dilin beyanıdır.

Anahtar kelimeler: Mevlânâ, metafor, köpek, nefs, şeytan, câhillik, aşk.

\section{The Metaphor of Dog in Mawlana's Masnawî}

\begin{abstract}
Depicting the principles of human lives through animal stories in the world literature dates back to VI. century B.C. With these animal stories, basic issues related to human beings such as politics, morality and Sufism were lectured. The way the truth is narrated through animals is a consideration that has gained popularity in many civilizations. In the Muslim world, Mawlana drew attention to these issues with the animal characters he used in his Masnawî. Mawlana provided the understanding of abstract subjects based on concrete subjects with animal stories he used in his Masnawî. In this study, we discussed the metaphorical meanings attributed to the dog in Mawlana's Masnawî. In Sufism, while the dog is generally regarded as "ignorant person who pursues world goods and unawares of truth", it was used in negative metaphorical meanings such as "superstitious belief, cruel, evil, devotion to the world, soul-body difference, devil, self, to yield to flesh, desires and wishes, ignorance, to turn away from the ignorant, disbelieving hypocrisy, hypocrisy, shamelessness, thanklessness, false guides, getting angry, deprivation of love"; and positive metaphorical meanings such as "obedience to the God, seeking the God, to reach a good state, loyalty, love, love of God, friend of God, thinking, reasoning" in Masnawî. This study aims to contribute to the understanding of the nuanced language Mawlana uses through the character of the dog while explaining the truths about human beings.
\end{abstract}

Keywords: Mawlana, metaphor, dog, self, devil, ignorance, love.

Turkish Academic Research Review - Türk Akademik Araştırmalar Dergisi 


\section{Giriş}

Dünya edebiyatında çeşitli varlıklar üzerinden insanların hakîkatlerine dair esasların anlatılması yani hikâyeleştirilmesi ilk olarak M.Ö. VI. yüzyılda yaşayan Aisopes'e dayandırılır. Özellikle hayvanların konu edinildiği hikâyeler, Hintliler'den Mezomotamya'ya, İbrânîlere, İskitlere, Fenikelilere kadar geniş bir coğrafyada yaygınlık kazanmıştır. Bu hayvan hikâyelerinde siyaset, ahlak, tasavvuf gibi insanı ilgilendiren konulara temas edilmiștir. Mevlânâ (ö. 672/1273) da Mesnevî̀ sinde tasavvufî, dinî, felsefî, ahlâkî vb. hususiyetlerle ilgili mesajını aktarırken zaman zaman hayvan hikâyelerine başvurmuş, metaforik ${ }^{1}$ bir üslupla konuların daha etkili ve anlaşılır olmasını sağlamıştır. ${ }^{2}$ Mevlânâ'nın Mesnevî̀ sinde geçen hikâyeler, herkese hitap etme özelliğinden dolayı benzer eserlerden ayrışmıştır. Mevlânâ, geniş bir halk kitlesine hitap etme mecburiyetinden olsa gerek, Mesnevî́ de sayısı 50'den fazla hayvanla ilgili çeşitli hikâyeye yer vermiştir. ${ }^{3} \mathrm{Bu}$ hikâyelerde hayvanlar üzerinden insana ait hakîkatlere işâret edilmiştir. Biz de bu çalışmamızda Mevlânâ'nın Mesnevî’ sinde olumlu veya olumsuz çeşitli anlamlar yüklediği köpek metaforunu, olumsuz anlamlardan olumlu anlamlara doğru bir siralama ile inceleyeceğiz.

“Köpek, köpekgillerden, çok çeşitli türleri olan kelp, it, zağar, seg” gibi farklı isimleri olan ehlî hayvana verilen isimdir. "Alçak, aşağılık, pis, sefill" gibi mecâzî anlamlar taşıyan köpek kelimesi "başkalarına yaltaklanan kişiler" için de kullanılır. ${ }^{4}$ Tasavvuf kültüründe genellikle "nefsine uyarak dünyalık peşinde koşan,

\footnotetext{
1 "Metafor, bir ilgi veya benzetme sonucu gerçek anlamından başka anlamda kullanılan söz; bir kelimeyi veya kavramı kabul edilenin dışında başka anlamlara gelecek biçimde kullanmadır. Metafor, mecaz, istiâre'dir. Grekçe bir kavram olan metafor, "bir deyimi/ifadeyi, anlamlı bağlantısı olan bir başka ifade ile mecazî olarak anlatma" anlamında kullanılır. Söz konusu ifadeler arasında direkt bir bağlantı bulunmayabilir; fakat anlamlarının birbirlerini çağrıştırıcı özelliklerinin veya aralarında paralelliklerin bulunması gerekir. Bu yüzden metafor, "bir şeyin, kendisiyle orantılı (benzerlik ilişkisi dolayısıyla) bir başka şeyle mecazî bir anlayışla anlatılması" olarak da tanımlanır. Konuların metaforla anlatılması, felsefî̀ veya halkın anlamakta zorluk çekeceği konuların onların anlama düzeyine indirilerek anlaşılmasını sağlamaktır." Bk. Ramazan Yazçiçek, "Metafizik Alanda Sörf ya da Mecaz ve Semboller Üzerinden Anlamlandırma: Bir Anlatım Yöntemi Olarak Metafor", Milel ve Nihal, 9 (1) / 2012, s. 137; Mevlânâ insana ait meseleleri anlatırken hakîkatin idraklere ulaşması için bu yöntemi kullanmıştır. Bk. Hasan Çiçek, "Mevlana'nın Mesnevi'sinde Soyut Kavramların İfade Aracı Olarak Metafor", Yüzüncü Yll Üniversitesi Sosyal Bilimler Enstitüsü Dergisi, 22/2012, s. 88; "En genel mânâda "bir sözcüğü sözlük anlamı dıșında bir mânâ ile kullanma"ya karşıllk gelen eğretileme / metafor terimi, edebiyatta, özellikle de şiir dilinde başvurulan "bütün söz sanatlarl" na verilen ortak addır. Dolayısıyla metafor, bütün mecâzî ve benzetmeli anlatım türlerini ve söz sanatlarını içine alan bir "semsiye kavram " niteliğindedir." Bk. Ahmet Ögke, Vâhib-i Ümmî'den Niyâzî̀-i Mısrî’ye Türk Tasavvuf Düşüncesinde Metaforik Anlatım, Ahenk Yayınları, Van 2005, s. 11; Nihat Keklik, "Mevlânâ'da Metafor Yoluyla Felsefe", 1. Millî Mevlânâ Kongresi (Tebliğler), Selçuk Üniversitesi Basımevi, Konya 1986, s. 44.

${ }^{2}$ Bu konuda sık kullanılan hikayelerden biri de "Körlerin Fili Tarifi” meselidir. Bk. Rıfat Atay, "Dinsel Çoğulculuk Açısından Farklı Mevlâna Okumaları: Bir Çözümleme Denemesi," Harran Ü. Illahiyat Fakültesi Dergisi 16 (Temmuz-Aralık 2006), 88-89.

3 Özgün Baykal, "Mevlânâ'nın Mesnevî'sinde Hayvan Hikâye ve Motifleri”, Şarkiyat Mecmuası, İstanbul Üniversitesi Edebiyat Fakültesi Şarkiyat Enstitüsü, İstanbul Edebiyat Fakültesi Basımevi, V/1964, s. 23-26; Abdullah Öztürk, "Hayvan Hikâyelerinin Yorumunda, Hz. Mevlana’yı Batılı Fabl Yazarlarından Ayıran Özellikler”, T.C. Celal Bayar Üniversitesi Manisa Yöresi Türk Tarihi ve Kültürünü Araștırma ve Uygulama Merkezi Birinci Uluslararası Mevlânâ, Mesnevî ve Mevlevîhâneler Sempozyumu Bildirileri, Manisa 2002, s. 242.

${ }^{4}$ Mehmet Doğan, Büyük Türkçe Sözlük, İz Yayıncılık, İstanbul, 1996, s. 680.
} 
hakîkatten habersiz câhil kişi”" şeklinde değerlendirilen köpek ${ }^{5}$, Mesnevî̀ de, "bâtıl inanç, zâlim, kötülük, dünyaya düşkünlük, ruh-beden farklılığı, şeytan, nefs, nefse uymak, nefsî arzu ve istekler, câhillik, câhillerden yüz çevirmek, kâfir, münâfiklık, iki yüzlülük, hayâsızlık, tevekkülsüzlük, sahte mürşidler, gazaplanmak, aşktan yoksunluk" gibi olumsuz anlamlarda kullanıldığı gibi “Allah'a itaat, Mevlâ'yı aramak, sırra mazhar olmak, vefâ, aşk, Hak âşığı, Allah dostu, düşünmek, akletmek" gibi olumlu anlamlarda da kullanılmıştır. Bu anlam çeşitliliği, Mesnevî̀ de geçen metaforların zengin bir çerçevede ele alındığını göstermesi açısından önemlidir.

Kur'ân-1 Kerim'de köpek kelimesi üç âyette geçmektedir. Bu âyetlerden birisi A 'râf sûresinin 175-176. âyetleridir. Bu âyetlerde köpek Hz. Mûsâ döneminde yaşayan İsrailoğullarından bilgin ve duası kabul olunan Bel'am b. Baûrâ'nın küfre meylini anlatmak için mecâzî anlamda kullanılmıştır. İlgili âyetler şöyledir:

\begin{abstract}
"Kendisine kanıtlarımızı verdiğimiz, fakat onları bir kenara atan, bu yüzden şeytanın peşine düştüğü, nihayet azgınlardan olan kişinin haberini onlara anlat. Eğer biz isteseydik o kişiyi delillerimizle yüceltirdik. Fakat o dünyaya saplanıp kaldı, hevesinin peşine düştü. İşte böylesinin hali, kovsan da bıraksan da hep dilini çıkarıp soluyan köpeğin haline benzer. Âyetlerimizi yalan sayan topluluğun durumu işte böyledir. Şimdi sen bu kıssayı anlat, umulur ki iyice düşünürler.”
\end{abstract} bahsedilir:

Kehf suresinde de Ashâb-1 Kehf'in yanında bulunan köpekten şöyle "Uykuda oldukları halde sen onları uyanık sanırdın. Onları sağa sola
çeviriyorduk. Köpekleri de mağaranın girişinde ön ayaklarını uzatmış
yatmaktaydı. Eğer o insanları görseydin dönüp kaçardın ve
gördüklerin yüzünden içini korku kaplardı...6 Böylece (kıssayı
anlatarak insanları) onlardan haberdar ettik ki, Allah'ın vaadinin hak
olduğunu ve kıyametin şüphe götürmez olduğunu bilsinler. Bir zaman
insanlar aralarında Ashâb-1 Kehf’in durumunu tartışıyorlardı. Dediler
ki: "Üzerlerine bir bina yapın. Rableri onları daha iyi bilir." Onların
yöneticileri ise "Bizler, kesinlikle onların yanı başına bir mâbed
yapacağı" dediler. (Sonra gelenler) bilmedikleri konuda karanlığa taş
atar gibi tahminler yürüterek, "Onlar üç kişidir; dördüncüleri de
köpekleridir" diyecekler; "Beş kişidir, altıncıları köpekleridir"
diyecekler. "Onlar yedi kişidir, sekizincisi köpekleridir" diyecekler.
De ki: "Onların sayısını rabbim daha iyi bilir. Onlar hakkında bilgisi

5 Ögke, Vahib-i Ümmî'den Niyâzîli Mısrî'ye Türk Tasavvuf Düşüncesinde Metaforik Anlatım, s. 213.

${ }^{6}$ Kehf, 18/18.

Turkish Academic Research Review - Türk Akademik Araştırmalar Dergisi 
olan çok azdır. Artık onlar hakkında gerçeği açıklama dışında tartışmaya girme ve kimseden de onlarla ilgili bilgi isteme! ${ }^{7}$

Peygamber Efendimizin hadislerinde köpekle ilgili; öğretilmiş köpeğin avının durumu ${ }^{8}$, ekin sürmek ve çiftlik hayvanı olması dışında köpek edinmenin insanın amelini eksilttiği ${ }^{9}$, susuzluktan ölmek üzere iken su bulan, susuzluğunu gideren kimsenin aynı durumdaki bir köpeğin su ihtiyacını gidermesi ile Allah tarafından bağışlandığ ${ }^{10}$, içinde resim ve köpek olan eve girilmeyeceğ $i^{11}$, bir köpeğin bir yemek kabına banması neticesinde, kabın yedi kere yıkanması ${ }^{12}$, av, ekin sürmek ve çobanlık işleri dışındaki köpeklerin öldürülmesi ${ }^{13}$ gibi farklı konular yer almaktadır. Sûfî şahsiyetlerden Senâyî Hasan Şabânî (ö. 1154/1741?), bir nutk-i şerifinde Peygamberimize olan bağlılığını ifade ederken köpek metaforunu şöyle kullanmıştır:

İhtiyâr oldu Senâyî şefkat eyle hâline

Ey Cenâb-1 hazret-i fahr-i cemî’i- mürselîn.

Âsitânın kelbiyiz bekler kapunu rûz u şeb

Ol gedâ-yı bî sevâbı lütfuna eyle karîn

Niyâzî-i Mısrî (ö. 1105/1694) de, Deccâlleşmeyi anlattığı dizelerinde köpek metaforuna şöyle yer vermiştir:

Yeter anı sen horladun

Köpek olup çok hırladun

Çatladun $u$ hem gürledün

Gele Deccâl gele gele

Gör kim senün halün nola."14

\section{Bâtıl İnanç}

Mevlânâ, Yahudiyi bâtıl inancından dolayı köpeğe benzetmiştir. Bu hususu manzûm olarak şu şekilde ifade etmiștir:

\footnotetext{
${ }^{7}$ Kehf, 18/21-22.

${ }^{8}$ Muhammed b. İsmâîl Ebû Abdillâh el-Buhârî, El-Câmiu'l-Muhtasar (Sahîhu'l-Buhârî), thk. Muhammed Züheyr b. Nâsri'n-Nâsır, (Dâru't-Tavki'n-Necât, b.y., 1422), "Vüdû", 33.

${ }^{9}$ Buhârî, "Müzâraa", 3.

10 Buhârî, "Mezâlim ve'l-gasb", 24, "Vüdû", 33; Müslim b. El-Haccâc Ebu'l-Hasan elKuşeyri'n-Nîsâbûrî, El-Müsnedü'l-Sahihu'l-Muhtasar, thk. Muhammed Fuâd Abdülbâkî, (Daru İhyâi't-Türâsi'l-Arabî, Beyrut, t.y.), "Selâm", 153-154.

${ }^{11}$ Buhârî, "Libâs", 94; Müslim, "Libâs ve’z-zîne”, 87.

12 Müslim, "Tahâre", 93.

13 Müslim, "Müsâkāt", 54

14 Senâyî Hasan Şabânî, Dîvân-ı Illâhiyât, haz. Mustafa Tatcı, H Yayınlanı, İstanbul 2013, s. 250 .
} 
“O köpek Yahudi, bak, ne tedbirde bulundu? Ateşin yanına bir put dikti. "Kim bu puta taparsa kurtulur. Secde etmeyen, ateşin tam ortasına oturur" dedi."15

Mevlânâ, Zûnüvas'ın (ö. 525) Medine'ye gelip daha sonra Necran'a döndüğünde o zamanın Müslümanı olan Hristiyanları zorlayarak Yahudi olmaları için yaptığı zorbalıklara atıfta bulunarak bu hususun köpeklik olduğuna işaret etmiştir. Burada Zûnüvas'ın ateş kenarına put koydurması, onun Yahudilikle birlikte putperestliğin izlerini üzerinde taşıdığının bir göstergesidir. Zûnüvas mü'minleri maddî ve mânevî olmak üzere iki ihânete zorlamıştır. $\mathrm{O}$ zamanın mü'minleri olan Hristiyanları puta taptırması mânevî ihânete, ateșe atılmalarını istemesi ise maddî ihânete işârettir. ${ }^{16}$

Mevlâna hazretleri, hakîkate gözü perdeli olanları köpeğe benzetmiş ve bu hususu İslâm'ın yayılış sürecinde Hz. Muhammed (a.s.)’’n yaşadığı zorluklara telmihte bulunarak aktarmıştır. Hz. Peygamber, kendisine "Essâmü aleyke ya Eba'lKāsım" diyen Yahudiler'e "Essâmü aleyke" diye karşılık vermiştir. ${ }^{17}$ Yahudiler sözde bu selamlariyla Hz. Peygamber'in ölmesini temenni etmişlerdir. Hz. Peygamber de selama karşılık olarak bu temenniyi onlara yöneltmiştir.

"Uykudan münezzeh olan o aslan uykudaydı. İşte sana hem yumuşak ve hilm hem de korkunç ve heybetli bir aslan! Aslan kendini öylece uyur gösterir. Bütün bu köpekler de sahiden uyuyor, hatta ölmüş sanırlar!"18

Bu beyitlerde Mevlânâ, Hz. Muhammed (a.s.)'1 arslana benzetmiş ve kendisini uyuyor göstererek, abdiyyet makāmında ${ }^{19}$ beyan etmiştir. Onu uyumuş zanneden köpeklerden murad ise inkârcılardır. Abdiyyet makāmında olan âriflerin sünnet-i seniyyeye uymalarına da işâret vardır. ${ }^{20}$ Ayrıca Mevlânâ hazretleri bu beyitlerde hakîkati temsil etmenin yumuşak başlılığa delâletine temas etmiş ama "Ey peygamber! Inkârcılara ve münâfiklara karşı cihad et, onlara sert davran..." âyetinin gereği olarak da inkârcılara ve nifak ehline karşı mü'minin uyanık olmasının gereğini hatırlatmıştır. ${ }^{22}$

\footnotetext{
15 Mevlânâ Celâleddîn-i Rûmî, Mesnevî, Çev: Veled İzbudak, Millî Eğitim Bakanlığı Yayınları, İstanbul,1995, c. 1, b.n:763-764.

16 Tâhiru'l-Mevlevî, Mesnevî Şerhi, Şamil Yayınevi, İstanbul 2017, c.1, s. 457-458; Ahmed Avnî Konuk, Mevlânâ Celâleddîn-i Rûmî Mesnevî̀i Şerif Şerhi, haz. Komisyon, Kitabevi Yayınları, İstanbul 2009, c. 1, s. 269; Sarı Abdullah Efendi, Cevâhir-i Bevâhir-i Mesnevî, İstanbul 1287-1288, c. 1, s. 487. Mesnevi bağlamında Mevlana'nın Hristiyanlara bakışı için ayrıca bk.: Rıfat Atay, "Mevlana'nın Hıristiyanları, Hıristiyanların Mevlana'sı: Mesnevi Merkezli Çoğulcu Bir Okuma Denemesi," Mevlana Mesnevi ve Mevlevihaneler Sempozyumu Bildirileri (30 Eylül-01 Ekim 2006), Manisa 2007, ss. 51-56.

17 Tâhiru'l-Mevlevî, Mesnevî Serhi, c. 8, s. 978.

18 Mevlânâ, Mesnevî, c. 4, b.n: 3795-3796.

19 Abdiyyet (mutlak kulluk) makāmı kulun, "Hakk'ın dışındaki bütün otoritelerden ruhen âzâde olması, hiçbir şeyin kendisi üzerinde hak iddia edemeyecek bir mertebeye ulaşmasıdır. Dolayısıyla mutlak kulluk uzlet, halvet, fakr, terk ve melâmet gibi hallerle gerçekleştirilen bir makamdır. İbnü'l-Arabî bu makamın kendisi için de gerçekleştiğini, bu makamda iken hiçbir șeye sahip olmadığını, sahip olsa bile hemen onu bağıșlayarak ondan kurtulduğunu, mutlak kulluk (abdiyyet) makamının her mertebe ve hal gibi Hz. Peygamber'e ait bulunduğunu söyler." Bk. Semih Ceyhan, "Ubûdiyyet", TDV İslâm Ansiklopedisi, https://islamansiklopedisi.org.tr/ubudiyyet (31.10.2020).

${ }^{20}$ Konuk, Mesnevî̀-i Șerîf Şerhi, c. 8, s. 601.

21 Tevbe, $9 / 73$.

22 İsmâil Rusûhî Ankaravî, Mecmûatü'l-Letâif ve Ma'mûretü'l-Maârif Mesnevî Şerhi, Matbaa-i Âmire Yayınları, İstanbul 1289, c. 4, s. 883-884.
}

Turkish Academic Research Review - Türk Akademik Araştırmalar Dergisi 


\section{Zâlim / Kötülük / Dünyaya Düşkünlük}

Allah Teâlâ rahîm ve sabûr sıfatlarının gereği olarak kulun günahının cezasını hemen vermez. Kulun hatasından dönmesini bekler. Ancak kul, isyan ve zulümde haddi aşınca, inat edince kuduz köpek gibi herkese ve her şeye, özellikle dine saldırmaya başlayınca Allah'ın kahrının muhatabı olur. Mevlânâ, zulmü son dereceye ulaştıran kişiye köpek diye hitap etmiş ve ilâhî âdetin bir gereği olarak zulüm ile âbâd olunamayacağından dolayı o kişinin, ilâhî kahra muhatap olacağını beyan etmiştir. ${ }^{23}$

"Nasihatçiler: "İşi haddinden ileri götürme, inat hayvanını bu kadar
ileri sürme" dediler. Nasihatçilerin ellerini bağlayıp hapsetti. Zulmünü
birbirine uladı (biteviye ve daha fazla zulmeder oldu). "Madem iş bu
dereceye vardı. Ey köpek, sabret; kahrımız erişti!" diye bir ses
geldi." 24

Mevlânâ hazretleri dünyayı ölmüş hayvanın kokmuş cesedine benzetmiş, bu cesede düşkünlüğü köpek tabiatlı kişilere ait bir özellik olarak belirtmiştir. Hakîkat erleri yanında dünyanın hiçbir kıymeti yoktur. Oysa dünya hayatında mânevî aydınlığa erişmek ancak Îsâ (a.s.)'ın şahsında bir Allah elçisinin mesajına râm olmakla gerçekleşir.

"Ben üst geleyim de dünyayı zaptedeyim diye harb etmiyorum ki. Çünkü bu cihan murdardır, pistir. Ben böyle pis bir şeye nasıl harîs olurum? Köpek değilim ki ölünün perçemini çekip koparayım. Ben İsa’yım, ölüyü diriltmeye gelirim." 25

Mevlânâ hazretleri, kötülük yapan kişilerin tabiatını, saldırgan köpeğe benzetmiștir. Zira Allah dostları insanlara ayna olurlar. İnsanlar bu aynada fena hallerini görürler. Gördükleri zaman da velî kullara düşman olurlar. ${ }^{26}$ "Kalp akçe, sarrafın can düşmanıdır. Yoksula köpekten başkası düşman olur mu?"27

Köpeğin, üstü başı düzgün kıyafetli kișilere yaltaklanması, kuyruk sallaması, perişan kıyafetli kişilere de saldırması onun tabiatından kaynaklanır. "Hikâye edilmiştir ki, Bistam şehri ahalisi bir bayram günü namaz kılmak için şehrin dışarısındaki musallaya çıkmışlar, namazın edâsından sonra avdet etmiş. Kasabanın girișinde yatan bir köpek ahâlîden hiçbirine ses çıkarmadığ Bâyezid-i Bistâmî hazretlerine karşı havlamış ve ona saldırmış. Erbâb-1 dikkatten biri, bunun farkına varmış ve Hz. Bâyezid'e sebebini sormuş. Hazret demiş ki: "Biz cilalı ayna gibiyiz. Bize bakan kendini görür. Bu köpek de bende şekl-i habîsini gördü de ona saldırdı." ${ }^{28}$ Kalbi temiz olan kişiden elbette meşrep ve tabiatı bozuk, nefsânî arzularının peşinde olan kişiler rahatsız olacaklardır. Kalbi temiz kişiler, kendilerine bakanlara ayna olurlar. ${ }^{29}$

Mevlânâ hazretleri pislik içinde kalmış kişinin o pislikten nemalandığını ve onsuz yapamadığını, bayılan debbağı, kardeşinin köpek pisliği koklatarak ayılttığını belirtmiş, insanın alışkanlıklarının onun felaketi olabileceğine işâret etmiş, latîf

\footnotetext{
23 Tâhiru'l-Mevlevî, Mesnevî Şerhi, c. 1, s.501-502.

${ }^{24}$ Mevlânâ, Mesnevî, c. 1, b.n: 870-873.

${ }^{25}$ Mevlânâ, Mesnevî, c. 3, b.n: 4550-4553.

26 Mehmet Şahin, Bâkî Dîvânı'nda Ayna Metaforu, Journal of Social, Humanities and Administirative Sciences, 6 (25): s. 520.

${ }^{27}$ Mevlânâ, Mesnevî, c. 4, b.n: 26.

28 Tâhiru'l-Mevlevî, Mesnevî Serhi, c. 7, s. 11-12; Ankaravî, Mesnevî Serhi, c. 4, s. 17.

${ }^{29}$ Konuk, Mesnevî-i Şerîf Şerhi, c. 7, s. 27.
} 
ruhlara uygun olan latîf mânâlar, habîs ruhlara uygun olan habîs mânâlar olduğunu beyan etmiştir. Mevlânâ'ya göre kişi aslında alışkanlıklarının kölesidir. Köpek pisliğine alışan, hayatını ancak onunla devam ettirebilir. ${ }^{30}$
"O tabağın iriyarı, güçlü kuvvetli, bilgili anlayışlı bir erkek kardeşi vardı, hemencecik koşa koşa geldi. Yenine biraz köpek pisliği almıştı, halkı yardı, feryat ederek kardeşinin başucuna geldi. Ben neden hastalandı biliyorum, dedi. Hastalık teşhis edildi, sebebi bilindi mi tedavisi kolaydır. Sebebi bilinmezse tedavisi güçleşir. Hangi ilaç iyi gelecek? Yüz türlü ihtimal vardır. Fakat sebebi bilindi mi iş kolaylaşır. Sebeplerini bilmek, bilgisizliği giderir. Adam kendi kendine, onun iliğine damarına kat kat köpek pisliği sinmiştir. Rızkını elde etmek için her gün, akşamlara kadar pisliğe gömülmüştür, tabaklığa gark olunmuştur, demişti. Büyük Calinus da böyle demiştir: Hastaya, neye alışkınsa onu ver! Aykırı olan şeylerden zahmet çeker; onun için hastalığının ilacını da alıştığı şeylerde ara! Bokböceği, daima pislik taşır durur. Bu yüzden de gülsuyundan bayılır. Onun ilâcı yine köpek pisliğidir. Çünkü ona alışmıştır, onunla halli hamur olmuştur. "Pisler, pislerindir” âyetini oku da bu sözün önünü, sonunu anla!’31

Nûr sûresinde buyrulmuştur ki: "Kötü kadınlar kötü erkeklere, kötü erkekler kötü kadınlara temiz kadınlar ise temiz erkeklere, temiz erkekler de temiz kadınlara yakışır. Bunlar (o temiz kadınlar ve temiz erkekler) o iftiracıların diyeceklerinden çok uzaktırlar. Onlar için bir mağfiret ve çok şerefli bir rızık vardır."32 "Bu âyetin zâhiri, tayyib ve tayyibe olan Resulullah ile harem-i muhteremi Hz. Ayşe'ye işâret etmektedir. Bâtını ise her tayyib ve habîse olana şâmildir. İşte bayılmış olan debbağ da köpek pisliği ve kokmuş deri gibi habîs şeylerle meşgul olduğundan, onun devâsı da köpek pisliğinden olacaktır."33

Bir başka vecihle habîsten murâd, kâfir, münâfik ve fâsıklardır. Alıșkanlıklar kișinin ikinci tabiatıdır. Münkirlik bu tabiata yerleşti mi sanki oranın aslî unsuru haline gelir. Buradan salâh ve felâha kavuşmak ancak alışkanlıkların terki ve tabiatın fitrata uygun temizlenmesi ile mümkün olabilir. ${ }^{34}$

Mevlânâ hazretleri aşağıdaki beyitlerde Hz. Mûsâ'nın Kıptîyi öldürmesine telmihte bulunarak mânevî ölümün bedenin ölümünden daha fena bir hal olduğunu bildirmiş ve Firavun'un şahsında inananlara zulmedenlerin yaptığının ne büyük bir katliam olduğunu belirtmiştir. Hz. Mûsâ'nın Kıptîye vurduğu yumruk, hayvanlar gibi yaşamakta olan Kıptînin izâfî rûhunu ondan gidermiştir ki, peygamberlerin mâsumiyeti bu fiilin ancak ilâhî emirle gerçekleştiğini gösterir. ${ }^{35}$

\footnotetext{
${ }^{30}$ Konuk, Mesnevî-i Serîf Şerhi, c. 7, s. 93.

${ }^{31}$ Mevlânâ, Mesnevî, c. 4, b.n: 269-280.

${ }^{32}$ Nûr, 24/26.

33 Tâhiru'l-Mevlevî, Mesnevî Şerhi, c. 7, s. 72.

${ }^{34}$ Ankaravî, Mesnevî Serhi, c. 4, s. 62-63.

35 Konuk, Mesnevî̀-i Şerîf Şerhi, c. 8, s. 155.
} 


\begin{abstract}
"Ben bir kötü kişiyi öldürdüysem ne nefsime uyduğumdan öldürdüm ne de eğlence için! Ben bir yumruk indirdim o da derhal ölüverdi. Zaten canı yoktu, can verdi, geberdi gitti. Ben bir köpek öldürdüm. Fakat sen peygamber oğullarını, yüz binlerce suçsuz, ziyansız çocukları öldürdün ya! Onları öldürdün; hepsinin kanı senin boynundadır. Bakalım hele, bu kan içmeden başına neler gelecek? Yakup soyunu öldürdün. Maksadın da hep beni öldürmekti, bunu umuyor, bunu istiyordun sen!"36
\end{abstract}

Mevlânâ hazretleri, dünya peşinde koşanları köpeklere benzetmiş, dünya metâı olan bir kemik için onların birbirleriyle dalaşmasından hareketle dünyanın bizi çektiği çukura dikkatimizi çekmiştir." Zira "Dünya cîfedir, onun talipleri köpeklerdir." 38

"Bir kemik parçası için köpeklerle dalaşmakta, içi boş ney gibi inleyip durmaktasın. Bana öyle horlukla kötü kötü bakma ki damarlarının içinde dolaşan sırları söylemeyeyim." 39

Mevlânâ, insân-1 kâmilin mekân âleminden sıyrılmış ruhlar âleminde cevelân ettiğini ve dünya âlemine çakılıp kalan kişinin de kesâfet-i tabîiyye içinde köpekler gibi hır gür içinde olduğunu beyan etmiştir. ${ }^{40}$

"Biri Yusuf yüzlü, İsa nefesli. Öbürü bir kurt yahut çıngıraklı bir eşek. Biri Lâmekân âleminde uçmakta. Öbürü köpekler gibi samanlıkta kalakalmış!"41

\title{
3. Nefs / Nefsânî Arzu ve İstekler
}

Mevlânâ hazretlerinin beyitlerinde nefsin terbiyesinde rol oynayacak “aslan”, mecâzen Allah, enbiyâ veya evliyâ anlamında kullanılmıştır. Mesnevî̀ deki bu aslan kelimesi nefis aslanı, şeytan aslanı veya gazap aslanı diye nitelendirilmiștir. ${ }^{42}$ İnsânî tabiatın terkedilmesi, ahlâken köpeklik sıfatına sahip olmak demektir. Bu da ilâhî kahrın aslan sûretinde tecellî etmesine sebep olur. ${ }^{43}$

"Böyle olunca yalvarmaya başla, ağlayıp inlemeye, tesbihe, oruca devam et! "Rabbim, sen gaipleri bilirsin. Günahtan dolayı bizden intikam alma” diye yalvar, yakar! "Ey aslanları yaratan! Eğer biz bir köpeklik etmişsek bu pusudan bizim üstümüze aslanı saldırma!"44

\footnotetext{
${ }^{36}$ Mevlânâ, Mesnevî, c. 4, b.n: 2330-2334.

37 Konuk, Mesnevî- $i$ Şerîf Serhi, c. 2, s. 121; Sarı Abdullah Efendi, Cevâhir-i Bevâhir-i Mesnevî, c. 3, s. 185.

38 İsmâil b. Muhammed el-Aclûnî, Keșfü'l-Hafâ ve Müzîlü'l-İlbâs, thk. Abdülhamîd b. Ahmed b. Yusuf b. Hindâvî, (El-Mektebetü'l-Asriyye, b.y. 1420 / 2000), c. 1, s. 464.

${ }^{39}$ Mevlânâ, Mesnevî c. 1, b.n: 2325-2329.

${ }^{40}$ Konuk, Mesnevî̀-i Şerîf Şerhi, c. 4, s. 86.

${ }^{41}$ Mevlânâ, Mesnevî, c. 2, b.n: 2110-2111.

42 Tâhiru'l-Mevlevî, Mesnevî Şerhi, c. 2, s. 648; Ankaravî, Mesnevî Şerhi, c. 1, s. 263- 264.

43 Konuk, Mesnevî-i Serîf Serhi, c. 1, s. 373.

${ }^{44}$ Mevlânâ, Mesnevî, c. 1, b.n: 1195-1197.
} 
"Kur'an'da "Allah sevgisiyle fakire, yetime ve esire yemek yedirirler."45 âyet-i celîlesi vardır. Bu sûrenin nüzûlüne sebep olan vâkıa şudur: Hz. Peygamber’in sevgili kerimesi Fâtıma ile zevc-i mükerrimi Hz. Ali oruçlu bulundukları bir günün akşamında iftar etmek üzere bir parça arpa ekmeği tedârik etmişler. Sofraya oturacakları sırada kapıya bir fakir gelmiş, "Allah için bir şeyler verin" demiş. Bunun üzerine Hz. Ali ve Hz. Fâtıma ekmeği o fakire vermişler, başka yiyecekleri olmadığı için su ile iftar etmişler. Ertesi akşamki ekmeklerini öksüz bir çocuğa, üçüncü akşamın ekmeğini de bir esire vermişler. Sonra da: "Onların ettikleri sabrın mükâfatı cennet nimetleriyle oradaki ipek libâslardır."46 va'd-i ilâhîsine nâil olmuşlardır. İște Allah yolunda koşup giden arslanlar böyledir. Kudurmuş bir köpek ve kokmuş bir leş halindekiler nasıl olur da bu arslanlarla adım atabilirler? Bunlarla yarışa çıkmak değil, hiç olmazsa yürüyebilmek için bu köpeklik ve lâşelik sıfatından kurtulmak lazımdır. Boğazından başka bir şey düşünmeyen kimsenin nefsi ise şüphe yok ki, emmâre derekesinden yükselmemiş, köpeklik gibi sıfatını tebdil edememiştir. Köpek çok beslenildiği takdirde azar, sahibine itaat etmemeye başlar. Karnı tokken isteye isteye ava gitmez olur. Nefs de buldukça bunar, doydukça iştahı açılır. Binaenaleyh onu açlık kamçısı ile yola getirmek mümkün olur." ${ }^{47}$

Mevlânâ hazretleri, yaşamda gâyenin ögün yemek olduğunu savunanların mânâ kapısını çalamayacaklarını belirtmiş, ledünnî ilme ulaşmada, nefsin arzu ve isteklerinin yeteri kadar yerine getirilmesininin önemini, hayvânî nefsi köpeğe benzeterek beyan etmiştir. ${ }^{48}$

"Mâna kapısını döversen açarlar. Fikir kanadını terk et ki seni iri bir doğan haline getirsinler. Fikir kanadı, çamurlara bulanmıştır, ağırdır. Sen toprak yemeğe alışmışsın; onun için toprak, sana can gibi geliyor. Ekmek et. Bunlar topraktır, bunları daha az ye de toprak gibi yeryüzünde kalma. Acıkınca kızgın geçimsiz, aslı kötü bir köpek oluyorsun. Karnın doyunca murdarlaşıyor, ayak üstünde duran ve hiçbir şeyden haberi olmayan bir duvar kesiliyorsun. Şu halde sen bir zaman pis, murdar bir hale geliyor, bir zaman köpekleşiyorsun. Aslanların yolunda nasıl yürüyebilecek, nasıl koşup seğirteceksin? Sana avlanmakta yarayan ancak köpektir. Bunu böyle bil de köpeğe daha az miktarda kemik at! Çünkü köpeğin karnı doyarsa daha ziyade serkeşleşir. Bu serkeşlikle ava istediğin gibi gider mi?"49

Hadîs-i şerifte insanın azılı düşmanının iki yanı arasındaki nefsi olduğu beyan edilmiştir. ${ }^{50}$ Nefsin kuvvetlenmesi, azgınlığının artmasına neden olur. Nefsin zayıflaması ise Allah'a olan yakınlığın artmasına vesile olur. Aşağıdaki beyitlerde kemik insan bedenini, köpek ise nefs-i emmâreyi temsil etmektedir. Beden, nefsin

\footnotetext{
45 İnsân, $76 / 8$.

46 İnsan, 76/12.

47 Tâhiru'l-Mevlevî, Mesnevî Şerhi, c. 3, s.1352-1353.

${ }^{48}$ Konuk, Mesnevî-i Şerîf Şerhi, c. 2, s. 272-273; Ankaravî, Mesnevî Şerhi, c. 1, 543; Sarı Abdullah Efendi, Cevâhir-i Bevâhir-i Mesnevî, c. 4, s. 99-101.

${ }^{49}$ Mevlânâ, Mesnevî, c. 1, b.n: 2870-2877.

${ }^{50}$ Aclûnî, Keşfü'l-Hafa ve Müzîlü'l-İlbâs, c. 1, s. 161; Nefsin çeşitleri için bkz. Mehmet

Şahin, Etvâr-1 Seb`a geleneği ve Vâhib Ümmî’de Etvâr-1 Seb‘a, Turkish Studies - Religion, 15(1), 77-96. https://dx.doi.org/10.29228/TurkishStudies.40030, s. 80.
}

Turkish Academic Research Review - Türk Akademik Araştırmalar Dergisi 
arzularının peşinden gittikçe, önüne kemik atılmış köpek gibi olur ve güçlenir, bu halde iken de mânâ âleminin zevklerinden mahrum kalır. Bedenin arzularına göre yaşamak ise ibâdetleri yaparken "namaz kılarsam bacaklarım ağrır, oruç tutarsam zayıflarım" gibi bahanelerle rûhânî lezzetlerden uzak kalmaya sebep olur. ${ }^{51}$ Nefs-i emmâre mertebesinde sâlik, köpek tabiatlıdır ve bedenî arzulara âşıktır. ${ }^{52}$

"Sen de kendine gel, köpek nefsini diriltmeyi isteme. Çünkü o nice zamandır senin düşmanındır. Bu köpeği can avından alıkoyan kemiğin başına toprak! Köpek değilsen neden kemiğe âşıksın, sülük gibi neden kanı seviyorsun?"53

Mevlânâ, terbiye edilmemiș nefs ile terbiye edilmiș nefsin karşılaştırmasını köpek metaforu üzerinden yaparak, aşağılık nefsin nasıl azîz olabileceğini şöyle anlatır:

“Ay bile yoksulların izi tozunu gözüne sürme gibi çektiği halde, köpek, kızgınlıkla yoksullara saldırır. Kör, köpeğin sesinden korktu, âciz oldu. Ona tâzim etmeye başladı: "Ey avcılar beyi, ey av aslanı, el senin elin (hüküm senin hükmün), benden el çek" demeye başladı. Hakîmin biri de zaruret yüzünden eşeğin kuyruğunu ağırlamış, o kuyruğa Kerim lâkabını takmıştır. Kör de zora gelince köpeğe "Ey aslan, benim gibi arık birisini avlayıp da ne yapacaksın? Dostların çölde yaban eşeği avlamaktalar, sense mahallede kör avliyorsun, bu ne kötü şey! Dostların avda yaban eşeği arıyorlar, sen sokakta hile düzüp kör arıyorsun” dedi. Bilgili köpek yaban eşeği avlar, bilgisiz köpekse köre kasteder. Köpek bile, ilim öğrenince azgınlıktan kurtulur, ormanlarda helâl hayvanlar avlar. Köpek bile âlim olunca savaşta çevikleşir. Köpek bile ârif olunca Eshâb-1 Kehf'ten olur. Köpek bile avcıları kimdir, anlar, tanır. Yarabbi, her şeyi tanıtan o nur nedir ki? Körün tanıamaması, gözü olmadığından değildir; bu, onun bilgisizlikten sarhoş olması yüzündendir. Kör, bu yeryüzünden de daha gözsüz değil ya! Halbuki bu yer bile Allah inayetiyle düşmanı tanıdı! Musa'nın nurunu gördü, ona iltifat etti, Karun'u ise tanıdı yere geçirdi." 54

"Burada köpekten maksat insanın nefsidir ki, talim ve terbiye ile islah olur ve muallem av köpeğine benzer ki, avlayıp getirdiği helal olur. Tezkiye ve sslah olunmayan nefis ise gayr-i muallem köpek gibidir, avı yakalayacağı yerde insana saldırır." ${ }_{55}$ Harp ilmini bilen kimse savaşta düşmanını avlar. Câhil kimse köpeğe benzetilmiş, bu haliyle onun faydasız olduğu, ancak ilim öğrenerek dalâletten kurtulacağı belirtilmiştir. ${ }^{56}$ Köpeğin cehlini gidermesi yani âlim olması, düşmanla

51 Tâhiru'l-Mevlevî, Mesnevî Şerhi, c. 4, s. 166-167; Konuk, Mesnevî̀-i Şerîf Şerhi, c. 3, s. 142.

52 Ankaravî, Mesnevî Şerhi, c. 2, s. 86.

${ }^{53}$ Mevlânâ, Mesnevî, c. 2, b.n: 474-476.

${ }^{54}$ Mevlânâ, Mesnevî, c. 2, b.n: 2355-2363.

55 Tâhiru'l-Mevlevî, Mesnevî Serhi, c. 4, s. 735.

${ }^{56}$ Konuk, Mesnevî̀-i Şerîf Şerhi, c. 4, s. 149. 
mücâdele ve savaşma gücüne erişmeye işâret eder. Bu mânâda köpek, Ashâb-1 Kehf'in köpeğinin mertebesindedir. ${ }^{57}$ bildirmiştir:

Mevlânâ hazretleri şeyh ile dost olanın köpek nefse galip geleceğini şöyle

"Nefis şeyhle adım attığını, ona uyduğunu görürse zorla sana râm olur. Öküz sahibi de Davud'un sözünü anlayınca râm oldu. Şeyh sana dost oldu mu avda aklın, köpek nefse galip olur." 58

Uyuyan arzular, onları tahrik eden unsurların etkisiyle harekete geçerler. Mevlânâ, nefsânî arzuları, üzerine köpeklerin üşüştüğü leşe benzetmiştir. Köpeğin iki kötü huyu vardır. Birisi kuyruk sallayıp yaltaklanmak, diğeri öfkelenip saldırmaktır. Her iki hal de köpeğin kötü halleridir. Dünyaya meyli olanlarda da bu iki hal vardır. Ellerinde imkân yokken insanlara yaltaklanırlar, ellerine güç ve firsat geçince de emellerine engel olanları kahrederler. Onların bu hali ateşe atılınca zayıf düşen odunun haline benzer. Nefsânî arzularının peşinde koşanlar köpeklere benzetilerek Mesnevî̀ de şöyle açıklanmıştır. ${ }^{59}$

\begin{abstract}
“İstekler uyumuş köpeklere benzer. Onlardaki hayır ve şer de gizlidir. Kudretleri olmadığı için bunlar, yere yatmış odun parçaları gibi yata kalmışlardır. Fakat aralarına pis bir şey atıldı $\mathrm{m}$ adeta köpeklere hırs sûrunu üfürür. O sokakta bir eşek düşüp öldü mü uyuyan yüzlerce köpek uyanır. Gayb gizliliğine gitmiş olan hırslar, yenlerinden yakalarından baş çıkarır, hücuma koyulurlar. Her köpeğin kılları diş kesilir hile için kuyruk sallamaya başlarlar. Köpeğin belden aşağıs1 hile, belden yukarısı öfke olur, odun bulmuş zayıf ateşe döner. Mekânsızlık elinden yalım, yalım gelip çatar, ateşten çıkan alev ta göğe kadar, ağar. Bunun için yüzlerce köpek de insanın bedeninde uyumuştur. Bir av olmadığı için onlar, adeta gizlenmişlerdir."
\end{abstract}

"İnsanda hayır için de şer için de birçok meyil vardır. O meyiller bir kudret buluncaya kadar odun gibi yatarlar ve köpekler gibi uyurlar. Fakat bilhassa şer için kudret ve firsat bulununca leş görmüş köpekler gibi sıçrarlar ve yanmış odunlar gibi her şeyi yakarlar. Hepsi de dirilmiş ölüler gibi yattığı yerden firlarlar. Köpek, gücü yetmeyecek bir şey için kuyruk sallamak suretiyle yaltaklanır. Gücü yettiğine de saldırır ve dişleriyle ısırır. İşte yarısı hile, yarısı gazap bu demektir. Bu tabiatta bazı insanlar da vardır ki, kendinden üstün kimselere karşı köpekçesine yalvarırlar. Fakat kendinden aşağı kimselere karşı çok kibir ve büyüklük gösterirler. Keza ateş de böyledir. Yakacak bir şey bulamazsa zayıflar, sönmek ve kül olmak üzere bulunur. Fakat içerisine odun ve kömür atılınca yeniden parlar."61

Mevlânâ hazretleri, nefsânî arzularına uyan, rahatı seven kişilerin niteliklerini köpeğe benzeterek, Hakk'ın razı olduğu insanların riyâzetle yüce mertebelere ulaşabileceğini şöyle ifade ediyor:

\footnotetext{
${ }^{57}$ Ankaravî, Mesnevî Şerhi, c. 2, s. 374.

${ }^{58}$ Mevlânâ, Mesnevî, c. 3, b.n: 2545-2547.

${ }^{59}$ Konuk, Mesnevîi $i$ Şerîf Şerhi, c. 9, s. 225-226; Ankaravî, Mesnevî Şerhi, c. 5, s. 168-169.

${ }^{60}$ Mevlânâ, Mesnevî, c. 5, b.n: 626-634.

61 Tâhiru'l-Mevlevî, Mesnevî Şerhi, c. 8, s. 184-186.
}

Turkish Academic Research Review - Türk Akademik Araştırmalar Dergisi 
"Perdelerin yırtılması, maymun huylulara neler etti? Peygambere benzeyenlerse ibadetleri, ne faydalar verdi! Mamur yerlerde kuduz köpekler vardır. Yücelik ve nur definesi, yıkık yerlerdedir. Şu doğma, ayın tutulmasında olmasaydı bunca filozof, yolu kaybeder miydi hiç? Akıllı fikirli kişiler, bu yol yitirme yüzünden burunlarının üstünde ahmaklık dağını gördüler!"62

Yukarıdaki beyitlerde görünüşlerin insanı aldattığı belirtilmektedir. Mamur yerler, mal ve makām sahibi dünya ve hevâ ehlini simgelemektedir. Y1kık yerler ise, bedenleri dert ve mihnet, külfet ve meşakkatle harap olan belâ ehline işârettir. Bedenleri nimet ve rahatla mâmur olan kimselerin vücutlarında köpek sıfatları, hayvan huyları vardır. Bedenleri, ızdırapla, mihnetle harap olan kişilerin vücutlarında izzet ve nûr definesi vardır. Onlar Hakk'ın verdiklerine râzıdırlar. Her hallerinde Allah'a hamd ve senada bulunurlar. Kalpleri mârifet nûruna, yücelik hazinesine mekân olmuştur. Bazı akıllı geçinen kişiler; görünüşlerinin ötesine geçmezler, aldanırlar, hakîkati bulamazlar. Onlar akıllarına güvenirler, yolu şaşırırlar. Filozoflar, ayın nûrunu yalnız doğmakta, karanlığı da batmakta gördüklerinden, ölümden sonraki hayatı akıllarına güvenerek inkâr ederler ve yolu şaşırırlar, hakîkati kaybederler. ${ }^{63}$

Mevlânâ hazretleri nefsine düşkün olan insanların şu dünyadan azıcık daha faydalanacaklarını şöyle ifade etmiştir:

"Şimdi zencilik zamanı. Rum diyarına mensup olanlar, beyaz güzeller gizli. Şimdi gece, güneş gizli. Kurdun devri, Yusuf kuyunun dibinde. Kıptilerin nöbeti, Firavun, padişah şimdi. Bu suretle de herkese lüzumlu, lüzumsuz gülüp duran ve kimseden esirgenmeyen rızıktan şu köpekler de birkaç gün rızıklansınlar, hisselerini alsınlar bakalım. "Gelin” buyruğu verilinceye kadar aslanlar, orman içinde beklemedeler. $\mathrm{Bu}$ emir geldi mi o aslanlar, yayıldıkları yerden çıkarlar. Allah, hicapsız olarak yayılacakları, geçinecekleri yeri gösterir." ${ }^{64}$

Nefsine ve midesine düşkün olan insanlar köpeğe benzer. Dünya ehlinden esirgenmeyecek olan rızık, cismânî rızıktır. Mü’min, kâfir herkese bu rızık verilir. Bu rızka nâil olup, rızkı vereni görmemek ahmaklık ve aldanıştır. ${ }^{65}$ Cismânî rızık peşinde koşanlar, hayvânî sıfatlara sahip nefsine düşkün insanlardır ki bunlar köpek tabiatlıdır. Bu köpek tabiatlı kişiler, ebedî nîmetlere karşılık dünya nîmetlerini tercih ederler. ${ }^{6}$ Şu âyet bu kişileri anlatmaktadır: "Kim âhiret kazancını isterse onun bu

${ }^{62}$ Mevlânâ, Mesnevî, c. 6, b.n: 1830-1833.

${ }^{63}$ Tâhiru'l-Mevlevî, Mesnevî Şerhi, c. 10, s. 215, Konuk, Mesnevî̀-i Şerîf Şerhi, c. 11, s. 591; Ankaravî, Mesnevî Serhi, c. 6/1, s. 442-443.

${ }^{64}$ Mevlânâ, Mesnevî, c. 6, b.n: 1870-1874.

65 Tâhiru'l-Mevlevî, Mesnevî Serhi, c. 10, s. 222.

${ }^{66}$ Konuk, Mesnevî-i Şerîf Şerhi, c. 11, s. 604. 
kazancını arttırırız; kim dünya kazancını tercih ederse ona da bundan veririz; ama onun âhirette hiçbir nasibi olmaz." 67

Mevlânâ hazretleri hevâ ve nefsine uyan kişilerin, ârif olan kişilerin ulaştıkları aşk, mârifet ve güzel nîmetlerden mahrum olduklarını köpeğin rızk olarak tutmaç suyuna müstehak olduğundan hareketle şöyle ifade etmiştir:

"Bâtın âleminde oturanların kıblesi lûtuf ve ihsan sahibi Allah'tır,

zâhire tapanların kıblesi kadın yüzü. Böylece eski yeni, say dur.

Usanırsan yürü, işine bak! Bizim rızkımız, altın kâse içindeki şarap,

köpeklerin rızk1, yal yedikleri yere dökülen tutamaç suyu." 68

“Şarap, aşk ve marifet şarabıdır. Köpekler, köpek tabiatlı ehli dünya, ashâb1 nefs ve hevâdır." 69 İrfan ehlinin rızkı leddünnî ilimde ve rabbânî mârifette ilâhî şarâb; nefsine düşkün kişilerin rızkı ise köpeğin yalağından tutmaç suyu içmektir. Yalak zâhirî sözleri, tutmaç suyu ise Mesnevî-i Şerîf'deki hikâyelerin ve kıssaların sûretini temsil eder. ${ }^{70}$

\section{4. Şeytan}

Hz. Ali'nin Hakk'ın arslanı olmasından hareketle Mevlânâ, arslanı köpeğin zıddına Hakk'a tapan, sûretten kurtulan kimse olarak nitelendirmiştir. Sûrete sahip olmak şeytanın vasfidır ki, şeytan köpeğe benzetilmiştir. ${ }^{71}$

"Sen azizleri (yani enbiya ve evliyayı) âdi insanlar gibi gördükçe bil ki bu görüş İblis'in mirasıdır. Be inatçı, İblis'in oğlu olmasan o köpeğin mirası nasıl olur da sana düşer? Ben köpek değilim, Allah aslanıyım. Allah aslanı suretten kurtulandır."72

Mevlânâ hazretleri bu manzûm ifadelerinde şeytanı köpeğe benzetmiş ve şeytanın insanları saptırmasına dikkatimizi çekmiştir. Şeytan Hakk’ın Mudill isminin tecellîsidir ve hadîs-i şerifte belirtildiğine göre insanın kan damarları içinde dolaşır. ${ }^{73}$ İnsanın şeytanın vesvesesinden kurtulmak için Allah'ın hükümlerine uyması gerekir, uymayan insan ise şeytanlaşmış bir insan ${ }^{74}$ sûretine dönüşür. ${ }^{75}$ Şeytanlaşmış insan artık ibâdet etmekten zevk almaz. Köpeklerin insana saldırması gibi şeytan da pek çok kimseyi Hak yoldan saptırmak için uğraşır durur. ${ }^{76}$

${ }^{67}$ Şûrâ, 42/20.

68 Mevlânâ, Mesnevî, c. 6, b.n: 1900-1903.

69 Tâhiru'l-Mevlevî, Mesnevî Şerhi, c. 10, s. 228.

${ }^{70}$ Konuk, Mesnevî-i Serîf Serhi, c. 11, s. 613; Ankaravî, Mesnevî Serhi, c. 6/1, s. 464.

${ }^{71}$ Konuk, Mesnevî- $i$ Şerîf Şerhi, c. 2. s. 555; Sarı Abdullah Efendi, Cevâhir-i Bevâhir-i Mesnevî, c. 5, s. 445-446; Ankaravî, Mesnevî Serhi, c. 1, s. 708.

${ }^{72}$ Mevlânâ, Mesnevî, c. 1, b.n: 3962-3964.

73 Muhammed b. Îsâ b. Mûsâ b. ed-Dahhâk et-Tirmizî, Sünenü't-Tirmizî, thk. Ahmed Muhammed Şâkir, Muhammed Fuâd Abdülbâkî, İbrâhîm Atvah, (Şirketü Mektebeh, Mısır 1975), "Radâ", 17.

${ }^{74}$ En'am, 6/112.

${ }^{75}$ Konuk, Mesnevî-i Serîf Serhi, c. 3, s. 180.

76 Ankaravî, Mesnevî Şerhi, c. 2, s. 105.

Turkish Academic Research Review - Türk Akademik Araştırmalar Dergisi 
"Bu zindanda iman azığı azdır. Bu azığa sahip olanlar da köpeğin korkusundan 1stırap içindedir. Namazdan, oruçtan, yüz türlü çaresizlikten meydana gelen zevk azığını da gelip birden alır, götürüverir. Allah Şeytanından Allah'a sığınırım; ah, onun azgınlığından helâk olup gittik! Bir köpek ama binlerce kişiye saldırmada, kime saldırır, kimin kanına girerse o adam da şeytan kesiliverir."77

Mevlânâ, şeytanın hased, kin, düşmanlık, hile, kin gibi bariz özelliklerine vurgu yapmış, bu özelliklere sahip olan kişiye köpek diye hitap etmiştir.

"Ben hasetçiyim, işte böyle bir hasette bulundum. Düşmanım; işim, gücüm, hile ve kinden ibarettir" Muaviye, bunun üzerine "işte şimdi doğruyu söyledin, senden bu beklenir, lâyığın budur. Sen örümceksin, ancak sinek tutabilirsin. Halbuki ben sinek değilim, zahmet etme a köpek!"78

Mevlânâ hazretleri, Allah'ın katında en değersiz varlık olan şeytanı köpeğe benzetmiş, şeytanın Allah'tan uzak olanlar üzerinde tesirli olduğunu, Allah dostları üzerinde tesirinin olmadığı şöyle ifade etmiştir:

"Haşa; Tanrı, neyi dilerse o olur. O, mekân âleminde de hâkimdir, mekansızlık aleminde de. Hiçbir kimse, onun ülkesinde onun emri olmadıkça bir kılı bile kımıldatamaz. Mülk onundur, ferman onun. Onun kapısında en aşağılık köpek, şeytandır, Türkmenin, kapısında bir köpeği olsa, o köpek, onun kapısına yüzünü, basını koyup yatsa, evin çocukları, kuyruğunu bile çekseler aldırmaz, onların ellerinde oyuncak olur. Fakat yoldan bir yabancı geçse erkek arslan gibi ona saldırır. Çünkü 'kâfirlere şiddetlidir', dosta gül gibidir, düşmana diken gibi."79

Şeytan, Allah'ın ihlaslı kulları üzerinde hükmünü icra edemez ${ }^{80}$, onlara köpek gibi diş geçiremez, ancak Hakk'ın dergâhından uzak kalanlar üzerinde onun hükmü geçer. ${ }^{81}$ Avni Konuk bu beyti, Allah'ın her şeyi kuşatan küllî irâdesiyle değerlendirmiş, "şeytan kim oluyor ki, Hakk'ın irâdesine muhâlefet etsin” diyerek, Aynu'l-Kudât Hemedânî'nin (ö. 525/1131) şu sözünü aktarmıştır: "Hak Teâlâ'dan başkasına nisbet edilen işi hakîki değil mecâzî bil! Fâil-i hakîkiyi Hak bil!"’82

Her şeyin yaratıcısı Allah olduğu gibi, elbette şeytanı da yaratan Allah’tır. Bütün varlıkların Allah'ın takdirine boyun eğdikleri gibi, şeytan da ilâhî hüküm için

\footnotetext{
${ }_{77}$ Mevlânâ, Mesnevî, c. 2, b.n: 635-638.

${ }^{78}$ Mevlânâ, Mesnevî, c. 2, b.n: 2785-2787.

${ }^{79}$ Mevlânâ, Mesnevî, c. 5, b.n: 2937-2943.

${ }^{80}$ Hicr, 15/40; Sa'd, 38/83.

81 Tâhiru'l-Mevlevî, Mesnevî Serhi, c. 9, s. 362.

${ }^{82}$ Konuk, Mesnevî-i Şerîf Şerhi, c. 10, s. 263.
} 
kurban olmuştur. ${ }^{83}$ İyi veya kötü bütün insanlar, Ashâb-1 Kehf' in köpeği gibi, dünya mağarasının önünde Hak Teâlâ'nın takdirini beklemektedir. Şeytan Allah'tan aldığg vazifenin gereği olarak, Hak yolda olanla bâtıl yolda olan ayırt edilsin diye âdeta mağarayı yabancılardan koruyan Ashâb-1 Kehf'in köpeği gibi insanları Allah'tan uzaklaştırmaya çalışan bir köpektir. ${ }^{84}$

“Peki, köpek şeytanı da Tanrı yaratmıştır. Onda yüzlerce düşünce, yüzlerce hile halk etmiştir. İyinin, kötünün yüzsuyunu gidersin diye yüzsularını ona gıda etmiştir. Halkın yüzsuyu, ona verilen tutmaç suyudur. Şeytan bunu yer, bununla doyar. Böyle olduğu halde nasıl olur da canı, kudret otağının önünde kurban olmaz? İyilerden de kötülerden de sürü sürü nice kişiler var ki ayaklarını yere döşemiş, köpek gibi o kapıya yönelmiştir. Hepsi de Tanrılık mağarasının eşiğinde köpek gibi yatmışlar, zerre zerre buyruk beklemede, kulak kabartmadalar. Ey köpek şeytan, halk bu yola ayak bastı mı onları sına. Saldır onlara, onları buraya koma. Bu suretle bak bakalım, doğrulukta hangisi er, hangisi dişi? "Tanrıya sığınırım” neden denir? Köpek, kızıp saldırmaya başlayınca değil mi? Ey Hıta Türkü "Tanrı'ya sığınırım" demek, köpeğe bağır, yolu aç da. Otağının kapısına geleyim, senin cömertliğinden bir hacet dileyeyim demektir."85

Mevlânâ, eski elbiseli Hak yolcusunun yolunu kesen şeytanı köpeğe benzeterek, şeytanın yol kesiciliğine dikkatimizi çekmiştir. ${ }^{86}$

"Veliyi meşhur eden yine velidir. Veli, kime dilerse nasip verir. Fakat deliliğe vurdu mu kimse akıl edip de onu anlayamaz. Bir hırsız, körden bir şey çaldı mı kör, onu bulabilir mi hiç? Hırsız, gelip ona çatsa bile kör, hırsız kimdir? Ne anlasın? Köpek, kör yoksulu ısırsa bile kör, kendisini dalayan köpeği nereden bilecek?" 87

\section{Câhillik / Câhillerden Yüz Çevirmek}

Mevlânâ, kemâl sahibi insanların câhillerin câhillikleri karşısında doğru bildikleri yolda yürüdüklerinden bahsetmiş ve yapılan câhillikleri köpeklerin havlamasına benzetmiştir.

${ }^{83}$ Ayrıca, şeytanın isyanının Mesnevi'deki hayli farklı ve estetik bir yorumu için bk.: Rıfat Atay, "Bilgi ve Bilgi ve Eylem Arasında Mevlana'da Estetik Değerler Eğitimi: Mesnevi Merkezli Bir Okuma Denemesi” Eğitimde Gelecek Araylșları Dünden Bugüne Türkiye'de Beceri Ahlak ve Değerler Eğitimi, Arzu Güvenç Saygın, Murat Saygın, Ed., (Ankara: Atatürk Araștırma Merkezi Yayınları, 2016), ss.1233-1247.

84 Tâhiru'l-Mevlevî, Mesnevî Şerhi, c. 9, s. 362-365; Konuk, Mesnevî̀-i Şerîf Şerhi, c. 10, s. 267.

${ }^{85}$ Mevlânâ, Mesnevî, c. 5, b.n: 2945-2955.

86 Konuk, Mesnevî-i Serîf Serhi, c. 4, s. 147.

${ }^{87}$ Mevlânâ, Mesnevî, c. 2, b.n: 2349-2354.

Turkish Academic Research Review - Türk Akademik Araştırmalar Dergisi 
"Can birisini öperse, felekten, feleğin hışmından gam yer mi? Mehtaplı gecede ay, Simâk burcundayken köpeklerden, köpeklerin havlamasından ne korkusu olur? Köpek vazifesini yerine getirir, ay da ışığını yere döşeyip durur.""88

Mevlânâ, Simâk burcunu aya, halkın kötülemesini, dil uzatmasını da köpeklere benzetmiştir. ${ }^{89}$ Ay enbiyâ ve evliyâyı, köpek ise onların karşısındakileri temsil eder. ${ }^{90}$

Mevlânâ, aşağıdaki beyitlerde temsîli olarak enbiyâ ve evliyâyı temsil eden doğan kuşuna saldıran baykuşları, cehâletleri sebebiyle gereksiz yere saldıran mahalle köpeklerine benzetmiştir.

"Padişahtan ayrı düşmesi şöyle dursun, baykuşlar, başına vurmağa, güzelim kanatlarını yolmaya başladılar. Baykuşlar arasına "Kendinize gelin; doğan yerinizi, yurdunuzu almaya geldi” diye bir velveledir düştü. Mahalle köpekleri gibi hepsi de kızgın, korkunç bir halde garip doğanın başına üşüşüp hırkasını çekiştirmeye başladılar. Doğan, "Ben baykuşlara lâyık mıyım? Baykuşlara bunun gibi yüzlerce virane bağışladım. Ben burada kalmak istemem, padişaha dönmek isterim." 91

Mevlânâ, mahallenin köpekleri kendi kötü tabiatlarına ayna olduğu için bir fakîr gördüklerinde nasıl ona saldırıyorlarsa, köpek tabiatına sahip baykuşların da enbiyâ ve evliyâyı temsil eden doğana benzer şekilde saldırdıklarını beyan etmiştir. ${ }^{92}$ Mevlânâ'ya göre doğan enbiyâ ve insân-1 kâmili temsil eder. Baykuşlar da hakîkat karşısında havlayan köpeği temsil eder. ${ }^{93}$

Mevlânâ aşağıdaki beyitlerde, Mesnevî’nin Kur'ân'ın bir tefsiri olduğunu ve Mesnevî̀yi kınamanın Kur'ân'1 kınamak olduğunu, Kur'ân'1 dolayısıyla Mesnev仓̂̀ yi kınayanların köpek tabiatlı olduklarını belirtmiştir. ${ }^{94}$

“Ey kınayan köpek, sen hav hav edip duruyor da Kur'an'1 kınamakla hükmünden kendimi kurtarırım mı sanıyorsun? Bu o aslan değil ki ondan canını halâs etmeğe muvaffak olasın yahut kahrının pençesinden imanını kurtarasın! Kur'an, kıyamete kadar, ey kendilerini bilgisizliğe feda edenler, diye nida eder." ${ }^{95}$

Mevlânâ hazretlerine göre, Hak erleri câhillerin itham ve kınamalarına aldırmadan doğru bildikleri yoldan asla vaz geçmezler. $\mathrm{Bu}$ kararlı yürüyüş karşısında câhiller yine de bu kınamalarından vazgeçmezler. Çünkü hayatın temelindeki değişmez yasa, hak bâtıl mücadelesidir. Hz. Mevlânâ, bu durumu şu satırlarla anlatır:

\footnotetext{
${ }^{88}$ Mevlânâ, Mesnevî c. 2, b.n: 415-417.

${ }^{89}$ Konuk, Mesnevî̀-i Şerîf Şerhi, c. 3, s. 130.

${ }^{90}$ Ankaravî, Mesnevî Serhi, c. 2, s. 76.

${ }^{91}$ Mevlânâ, Mesnevî, c. 2, b.n: 1135-1139.

92 Konuk, Mesnevî̀-i Serîf Şerhi, c. 3. s. 320.

93 Ankaravî, Mesnevi şerhi, c. 2, s. 184-185.

${ }^{94}$ Konuk, Mesnevî-i Serîf Serhi, c. 6, s. 502.

95 Mevlânâ, Mesnevî, c. 3, b.n: 4282-4284.
} 


\begin{abstract}
"Dolunay, gökyüzünde geceleri yürür. Köpeklerin sesi yüzünden yürüyüşünü bırakmaz. Kınayanlar, senin dolunayına karşı köpeklere benzerler. Sana karşı ürüyüp dururlar! Bu köpekler, "Susun, dinleyin" emrine karşı sağırdırlar. Ahmaklıklarından senin dolunayına karşı hav havlayıp durmaktalar!"96
\end{abstract}

"Her asırda bulunan Hak erleri için, münkirlerin târiz ve tecâvüzleri de köpeklerin dolunaya karşı uluması gibidir." $97 \mathrm{Bu}$ beyitlerde “Kur'ân okunduğu zaman onu dinleyin ve susun"98 âyetine telmih vardır. Köpek gibi olan kişiler, Hakk'ın hitâbı karşısında sağır kesilirler. Hz. Peygamber'in tebliği karşısında da köpekler gibi ses çıkartarak hakîkati işitmekten kaçınırlar. ${ }^{99} \mathrm{~Hz}$. Peygamber asrından sonra Nebî'nin vârisi olanlara dil uzatanlar, kötü söz söyleyenler de köpek sıfatlı kişilerdir. ${ }^{100}$

Mevlânâ, Nûh (a.s.)'ın dâvetine karşı çıkanları, dünya lezzetlerinin tutkunu, Hak ve hakîkate kayıtsız kalmış köpekler gibi havlayan kişilere benzetmiştir. ${ }^{101}$ Nûh (a.s.), davetine karşı çıkan köpek tabiatlı kişiler karşısında hak bildiği yoldan gitmiștir. ${ }^{102}$

"Nuh, tam dokuz yüz yıl kavmini davet edip durdu. Her an da kavminin inkârı arttı. Fakat söylemeden vazgeçti mi? Hiç sükût mağarasına çekilmeye kalkıştı mı? Köpeklerin havlaması ile kervan, hiç yolundan kalır mı? Ay 1şı̆̆ı olan gecede dolunay, köpeklerin havlaması ile yürüyüşünü ağırlaştırır mı, dedi. Ay, ışı̆̆ını saçar, köpek de havlar durur. Herkes, yaratılışına göre bir hizmette bulunur. Takdir herkese bir hizmet vermiş, herkesi bir ise lâyık görüp iptilâya salmıştır. Ay der ki: Köpek, o pis sesini bırakmıyorsa ben ayım, gidişimi nasıl bırakırım ki?"103

Mevlânâ hazretleri, aşağıdaki beyitlerde de hakîkat ehlinin her hal ve şartta doğru bildiklerini yaptıklarını, câhillere takılmadıklarını beyan etmiştir.

“Ay, nûrunu saçar, köpek havlar durur. Hiç köpek, ayı kendisine ortak edebilir mi? Ay ışığı ile geceleyin yol alanlar, köpek havlaması ile yollarından kalırlar mi?"104

Kâmil şeyh derya mânâsınadır. Şeyhe ta'n eyleyen inkârcıların vasıfları ise köpeğin salyası gibidir. Köpeğin salyasından derya pis olmadığı gibi, hak yolda

\footnotetext{
${ }^{96}$ Mevlânâ, Mesnevî, c. 4, b.n: 1464-1466.

97 Tâhiru'l-Mevlevî, Mesnevî Șerhi, c. 7, s. 379.

98 A'râf, 7/204.

${ }^{99}$ Konuk, Mesnevî-i Serîf Serhi, c. 7, s. 423.

100 Ankaravî, Mesnevî Şerhi, c. 4, s. 307.

${ }^{101}$ Konuk, Mesnevî-i Serîf Serhi, c. 11, s. 18

102 Ankaravî, Mesnevî Şerhi, c. 6/1, s. 10

103 Mevlânâ, Mesnevî, c. 6, b.n: 10-16.

${ }^{104}$ Mevlânâ, Mesnevî, c.6, b.n: 287-288.
}

Turkish Academic Research Review - Türk Akademik Araştırmalar Dergisi 
olanlara, köpek tabiatlı olan kimselerin kötü sözleri zarar vermez. Ay gibi etrafa 1şık saçan insân-1 kâmilin mârifet nûrundan, köpek tabiatlı kişiler nasîbdâr olamazlar. ${ }^{105}$

\section{Kâfir}

Mevlânâ hazretleri, kâfirin sesinin çirkin olduğunu ve küfre çağıran bu sesi halka kötülük yapmaktan ne yaptığını bilmez hale gelen sarhoş köpeğe benzeterek şöyle beyan etmiştir:

"Kâfirin sesi çirkin olduğundan icâbete eş olamaz. "Susun" emri, kötü ses hakkındadır. Çünkü o ses, halkın kanından köpek gibi sarhoş olmuştur.”106

Mevlânâ hazretleri, kâfirin dâvetine icâbet edilmeyeceğini belirtmiştir. $\mathrm{Bu}$ beyt ile şu ayete telmih vardır: "Rabbimiz! Bizi buradan çıkar; ĕger (çıkar da) bir daha eskiye dönersek, artık belli ki biz zalim insanlarız." Allah buyurur ki: "Yıkılın karşımdan! Ve artık bana bir şey söylemeyin!"107 "Yı1kılın karşımdan” hitâbı kötü sözlü kişilere yöneliktir. Kötü sözlü kişiler, halkın malını yiyen, gıybetini yapan, onlara kötülük yapan köpek tabiatlı kişilerdir. ${ }^{108}$

Mevlânâ, aşağıdaki beyitlerde köpeği Allah'ın dışındaki otoritelere boyun eğenlere, zalim ve mütekebbir olan hükümdârlara, beylere ve servet sahiplerine benzetmiştir. Bu köpek tabiatlı kişilere ancak alçak tabiatlı dünya ehli kişiler hürmet ederler. $\mathrm{Bu}$ alçak tabiatlı kişiler peygamber veya evliyâya hürmet etmekten utanırlar. ${ }^{109}$ Burada şu âyeti hatırlamak gerekir: "Pis şeyler pis olanlar içindir, pis olanlar da pis şeylere lâyıktır. Temiz şeyler temiz olanlar içindir, temiz olanlara da temiz şeyler yakışır..." 110

“İyi bak, kendine gel! Allah, padişahları etten, kemikten küçücük bir kap1 olarak halk etti ya. Dünya ehli olanlar, onlara secde ederler. Çünkü Allah'a secde etmenin düşmanıdır onlar! Dünya ehline bir fışkı yerceğizini mihrap düzdü. $\mathrm{O}$ mihrabın adı da bey, padişah! $\mathrm{Bu}$ tertemiz kapıya lâyık değilsiniz ki. Temiz kişiler, şeker kamışıdır, sizse bomboş birer kamıştan ibaretsiniz. O çeşit köpeklere elbette bu çeşit bayağılık adamlar hürmet ederler. Öyle âdi kişiye hürmet etmek, öyle âdi adama inanmak, aslana ardır." 111

Mevlânâ hazretleri, kâfirleri köpeklere benzeterek, onların şeytanlar tarafından hidâyet ehline saldırmak için eğitildiklerine ${ }^{112}$ dikkatimizi şöyle çekmiştir:

“Şeytanlardan yüz binlerce kötü huylar öğrenmişler, akıl ve gönül gözünü kapamışlardır. Onların kötü huylarından en ehemmiyetsizi

\footnotetext{
105 Ankaravî, Mesnevî Şerhi, c. 6/1, s. 513-515.

106 Mevlânâ, Mesnevî, c. 2, b.n: 2005-2006.

107 Mü'minûn, 23/107-108.

108 Ankaravî, Mesnevî Serhi, c. 2, s. 326-327; Konuk, Mesnevî-i Serîf Serhi, c. 4, s. 60.

109 Konuk, Mesnevî̀- $i$ Şerîf Şerhi, c. 6, s. 164; Kadir Özköse, "Mevlânâ'nın Öğretilerinde Kulluk Bilinci”, Somuncu Baba Aylık Ilim Kültür ve Edebiyat Dergisi, 21/170 (2014), s. 26.

110 Nûr, 24/26.

111 Mevlânâ, Mesnevî, c. 3, b.n: 2998-3002.

112 Konuk, Mesnevî̀- $i$ Şerîf Şerhi, c. 8, s. 258.
} 
hasettir, hani iblisin boynunu vuran haset! O köpekler, bunlara ululuk ve haset öğretmişlerdir, onlar, halkın ebedî bir mülke, bir devlete nail olmasını istemezler." 113

\section{Münâfıklık / İki Yüzlülük}

Hz. Mevlânâ, Firavun ve Firavunlaşan insanların güzel görünmeye çalıştıklarını ama hakîkat karşısında bütün pespayeliklerinin, iki yüzlülüklerinin ortaya çıktığını köpek metaforu ile şöyle anlatmıştır:

"Ey Firavun, arınmışlık iddiasında bulunma! Sen çakalsın, hiç boşuna tavusluk taslama. Tavusların yanında görünürsen, süzülmekten âciz olduğun için rezil olursun. Musa ile Harun, tavuslar gibiydiler ve süzülen kanatlarını senin başına yüzüne çarptılar. Çirkinliğin ve rezilliğin açığa çıktı ve yukarıdan aşağı tepetaklak düştün. Mihenge uğrayınca kalp altın gibi karardın. Aslan boyası gidip köpek açığa çıktı. Behey çirkin uyuz köpek, ihtiras ve azgınlık yüzünden aslan postuna bürünme. Aslan kükreyişi seni sınayacak. Görünüşte aslan, özde köpek olduğun sonunda anlaşılacak."114

Hz. Mûsâ ve Hz. Hârun karşısında Firavun'un tavrının değerlendirildiği bu beyitlerde, Firavun'un Tanrılık iddiasında bulunması, onun hadsizliğine ve kendi gerçekliğinden uzaklaşmasına bir işâret sayılmış ve bu bâtıl dâvasında Firavun'un ne kadar aslan postuna bürünse de gerçek kimliği olan köpeklik sıfatının ortaya çıkacağı belirtilmiştir. İnsanları kandırmak için köpek tabiatlı olan kişilerin kalbine dinî ilimler ve ahlâkî güzellikler giremeyecektir. Zira Hz. Peygamber "Içcinde kelb ve sûret olan eve melekler girmez." 115 buyurmuştur. ${ }^{116}$

Mevlânâ hazretleri kendisine emanet edilen eşeğe lâyıkı ile bakmayan ama bakmış gibi davranan hizmetçiyi iki yüzlü davrandığı ve işinin ehli olmadığı için köpeğe benzetmiştir.

"Nihayet biçare eşek, açlık illetinden o gece seher çağına kadar yan üstü yattı. Gündüz olunca, hizmetçi gelip hemen semerini düzeltti, sırtına vurdu. Eşekçiler gibi birkaç sopa indirdi. O köpek hizmetçiden ne umulursa eşeğe onu yaptı. Eşek dayağın, şiddetinden sıçradı, kalktı.

Dili yok ki halini söylesin!"'117

113 Mevlânâ, Mesnevî, c. 4, b.n: 2675-2677.

114 Mevlânâ, Mesnevî̀-i Ma'nevî, haz. Derya Örs, Hicâbi Kırlangıç, Türkiye Yazma Eserler Kurumu Baskanlığ 1 Yayınları, İstanbul 2015, s. 334, b.n: 782-788.

115 Buhârî, "Libâs", 94; Müslim, "Libâs ve'z-zîne", 87.

116 Ankaravî, Mesnevî Şerhi, c. 3, s. 137-138; Konuk, Mesnevî-i Şerîf Şerhi, c. 5, s. 219.

117 Mevlânâ, Mesnevî, c. 2, b.n: 240-243.

Turkish Academic Research Review - Türk Akademik Araştırmalar Dergisi 
Nasıl ki, ehil olmayan bir hizmetçi elinde eşek perişan olursa, nefs de ehil olmayan bir mürebbî tarafindan ıslâh edilemez. Mevlânâ, münâfıklık ve mürâîliği köpek sıfatı olarak belirtmiştir. ${ }^{118}$

Köpek gönüllü olmak, bâtının kötülüğüne, kedi gibi yüz yıkayıcı olmak zâhirin temizliğine işâret sayılmıştır. Lokma peşinde koşan sofiler, bâtınları kötü olduğu halde kendilerini iyi göstererek insanları aldatmaya çalışan köpeklere benzetilmiştir. ${ }^{119}$

“Boğazına düşkün, yemeye alışkın sofiler, köpek gönüllüdürler, fakat kedi gibi yüzlerini yıkarlar, temiz görünürler.”'120

Allah'ın hidâyetine nâil olamayan kişi muhtaç ve fakirdir. Fakat bu kimse Allah fakirinin ancak sûretidir. Mevlânâ, irfân ehlinden hakîkati öğrenme derdinde olmayanları köpek resmine kemik atılmasının anlamsızlığına işâret ederek, bu tarz kişilerin hakîkatten mahrum olacaklarını belirtmiştir. Zira bu kişiler ölü cesed gibidir, önlerine yemek tabağı koymanın bir anlamı yoktur. ${ }^{121}$ Sûreti derviş olanlara irfân sofrasından ikramda bulunmak ancak ziyana sebep olur, nîmet israf edilmiş olur. $^{122}$

“O kişi, yoksulun resmidir, canı yoktur, ekmek yemez. Köpek resmine kemik atma. O, Allah fakiri değil, lokma fakiridir. Ölü resmin önüne yemek tabağını koyma."123

Mevlânâ, fakirleri ikiye ayırmıştır: Fakîr-i lokma, fakîr-i Hak. Fakîr-i lokma, dünyayı talep eden, dünyaya aç kimse, fakîr-i Hak ise, Hakk'a, Allah'a aç, Allah'ı talep eden kimsedir. Mevlânâ'ya göre, fakîr-i lokma, sadece cennet peşinde koşan gâfil dervişler, fakîr-i Hak ise, Allah'1 isteyen hakîki dervişlerdir. ${ }^{124} \mathrm{Bu}$ görüş Yunus Emre'de şu dizelerle anlatılır:

Cennet cennet didükleri

Bir ev ile birkaç hûrî

İsteyene virgil anı

Bana seni gerek seni ${ }^{125}$

\section{Hayâsızlık}

Mevlânâ hazretleri, hakîkatten bîhaber olan kişileri zayıf insanlara saldıran hayâsız köpeğe benzeterek, hayâsızlığın sonucunun zulüm ve zâlimlik olduğunu şöyle ifade etmiştir:

"Davud, ondan sonra dedi ki. “A inatçı, bütün malını mülkünü hemencecik ona bağışla. Yoksa bak, sana söylüyorum, işin fena olur,

118 Tâhiru'l-Mevlevî, Mesnevî Serhi, c. 4, s. 90.

119 Konuk, Mesnevî̀-i Şerîf Şerhi, c. 3, s. 128; Ankaravî, Mesnevî Şerhi, c. 2, s. 75.

120 Mevlânâ, Mesnevî, c.2, b.n: 405.

${ }^{121}$ Konuk, Mesnevî̀-i Şerîf Şerhi, c. 2, s. 240; Ankaravî, Mesnevî Şerhi, c. 1, s. 525.

122 Sarı Abdullah Efendi, Cevâhir-i Bevâhir-i Mesnevî, c. 3, s. 500-501.

123 Mevlânâ, Mesnevî, c. 1, b.n: 2752-2753.

124 Tâhiru'l-Mevlevî, Mesnevî Serhi, c. 2, s. 1302-1303.

125 Yûnus Emre, Dîvân-ı İlâhîyât, haz. Mustafa Tatcı, Kapı Yayınları, İstanbul 2011, s. 525. 
yaptığın zulüm ve cefa meydana çıar.” Adam, bu söz üzerine başına topraklar serpip elbisesini yırtarak "Her an zulmünü artırıp durmaktasın" dedi. Yine bir müddet Davud'u kınamaya koyuldu, Davud, tekrar onu huzuruna çağırıp, Dedi ki: "Ey bahtı körleşmiş herif, mademki talihin yok, gayri yavaş, yavaş karanlıklar basmaya başladı. Senin gibi bir eşeğe çerçöple saman bile yazık. Öyle olduğu halde sen yine baş köşeyi gözetip duruyorsun ha! Yürü çocukların da onun kulu, kölesidir, karın da! Artık fazla söylenme!” Dâvacı iki eline taş almış, göğsünü dövmekte, bilgisizliğinden, bir aşağı, bir yukarı gidip gelmekteydi. Halk da Davud'u kınamaya başladı. Dâvacının gönlünde ne var, bilmiyorlardı ki, bir insan, saman çöpü gibi havaya kapılmış, maskara olmuşsa zalimi mazlûmdan nasıl fark edebilir? Zalimi mazlûmdan ayırt eden, zulümkâr nefsinin boynunu vurmuş kişidir. Yoksa içten içe nefse zebun olan kişi, deliliğinden mazlûmlara düşman kesilir. Köpek, daima yoksula, âcize saldırır, firsat bulursa ısırır da. Komşularından av kapmak aslanlara göre ayıptır, köpeklere değil, zalime tapan, mazlûmu öldüren kişilerin hepsi de pusudan çıkarak köpekçesine saldırdılar."126

Hz. Mevlânâ, Davud (a.s)'ın hükmüne itiraza kalkışan avam halkı, utanmazlıkta köpeğe teşbih etmiştir. Köpekler, fakir kimselere saldırdıkları gibi, köpek tabiatlı olanlar da Dâvud (a.s.)'a düşmanlık etmişlerdir. Çünkü hayâları ve dolayısıyla imanları yoktur. Bir hadis-i şerifte "Hayâ imandandır. Hayâ ile iman bir bütündür, ayrlmazlar, biri diğerini tamamlar. Şayet biri kaldırllacak olursa, diğeri de kalkar. "127 buyrulmuştur. ${ }^{128}$ Nefs-i emmâre köpek meşrebinde olan insan içindir. Hayâ ise arslan meşrebinde olan kimse içindir. Arslan tabiatı gereği başkasına ait olan bir şeyi almaz, köpek ise alır. Çünkü köpeğin hayâsı yoktur, hayâ ile iman yanyana bulunmaz. ${ }^{129}$

\section{Tevekkülsüzlük}

Hz. Mevlânâ, zor zamanda Allah'a güvenip tedbirler alacağına dair söz veren kişinin, kolay zamanda bu sözünden çok kolay vazgeçtiğini köpek mecâzı ile şöyle ifade etmiştir.

“Kış geldi mi köpek ezilir, büzülür. Kışın soğuğu onu perişan bir hale kor. "Kışa dayanamıyorum sağ olursam taştan bir ev kurmam lazım. Yaz gelince dişimle tırnağımla çalışıp çabalayayım, kışın barınmak için bir taş ev kurayım" der. Fakat yaz gelip de ısındı mı kellesi, kemiği yerine geldi mi, ilikleri, kemikleri kızışıp derisi gerildi mi, kendisini koskocaman görür de "iyi ama ben hangi eve sığarım ki?"

\footnotetext{
${ }^{126}$ Mevlânâ, Mesnevî, c. 3, b.n: 2425-2439.

127 Muhammed b. İsmâîl b. İbrâhîm b. el-Muğîre el-Buhârî, El-Edebü'l-Müfred, thk. Semîr b. Emîn ez-Zührî, (Mektebetü'l-Maârif, Riyad 1998), s. 739, h.n: 1313.

128 Tâhiru'l-Mevlevî, Mesnevî Şerhi, c. 6, s. 636-637.

${ }^{129}$ Konuk, Mesnevî-i Şerîf Şerhi, c. 6, s. 16; Ankaravî, Mesnevî Şerhi, c. 3 s. 397.
}

Turkish Academic Research Review - Türk Akademik Araştırmalar Dergisi 
der. İrileşir, ayağını çeker. Tembel tembel, karnı tok sırtı pek, kendisine güvenmiş bir halde bir gölgeye çekilir. Gönlü "Bir ev kur" derse de o, "söyle be yahu, ben nasıl olur da bir eve sığarım ki?" diye cevap verir. "Sen de bir belâya, bir musibete düştün mü büzülürsün, hırs kemiklerin bitişir; küçülür, kalırsın. "Tövbeden bir ev kurayım, kışın o evceğizde barınayım” dersin. Fakat dertten kurtuldun da hırsın büyüdü mü köpek gibi ev sevdası geçer gider."130

Hevâsına tabi olan kişinin, başı bir derde girdiği zaman nefsânî hırslarının katılığı, köpeğin kemikleri gibi zayıf olur. O dert ve bela içinde kıvranır durur, rahatlık zamanında da tedbir almaz. ${ }^{131}$ Nefs-i emmâreye dûçâr olan kişi, hatasında 1srar eder, durur, kendi hayrına gereken tedbirleri almaz. ${ }^{132}$

\section{Sahte Mürşidler}

Hz. Mevlânâ, kör yakalayan köpekten muradın gâfil avlayan müteşeyyihler (sahte mürşidler) olduğunu beyan ederek, kıymetli olan şeylerin sahtesi olduğu konusuna şöyle dikkatimizi çekmiştir. ${ }^{133}$

"Hani bir köpek, çukur içinde kör dilenciyi gördü de saldırdı, hırkasını yırttıydı ya! Bunu söyledik ama tekit için bir kere daha söylüyoruz. Kör dedi ki: Senin dostların şimdi dağlarda av arıyorlar. Hısımların dağda yaban eşeği avlıyorlar, sense köy ortasında kör tutuyorsun!"’134

\section{Gazaplanmak}

Hz. Mevlânâ aşağıdaki beyitlerde hakîkatte birbiriyle iyi ve dost olan baba ile oğlun arasının öfke sebebiyle bozulduğunu, oğlun bu durumda babasını köpek olarak gördüğünü, ancak bu görüntünün hakîkati perdelediğini ifade etmiştir. Bu durum, kardeşleri tarafından Yûsuf (a.s.)'ın kurt olarak görülmesindeki mânevî körlük gibidir. Öfke, hased gibi kötü huylar insanın sağlıklı düşünmesindeki önemli engellerdir. ${ }^{135}$

“Babanla aranda bir şey geçti mi babanı köpek gibi görürsün, gözüne böyle görünür! Baban köpek değildir senin; o cefanın tesiri ile öyledir, öyle bir merhametli adam bile sana köpek görünür! Kardeşleri Yusuf'a haset ediyorlar kızıyorlardı. Bu yüzden onu kurt şeklinde gördüler. Fakat babanla barıştın da kızgınlığın gitti mi köpek ortadan kalkar, baban, sana ateşli bir dost olur."136

\section{Așktan Yoksunluk}

\footnotetext{
${ }^{130}$ Mevlânâ, Mesnevî, c. 3, b.n: 2885-2894.

${ }_{131}$ Konuk, Mesnevî- $i$ Serîf Serhi, c. 6, s. 135

132 Ankaravî, Mesnevî Şerhi, c. 3, s. 476-477.

133 Tâhiru'l-Mevlevî, Mesnevî Serhi, c. 7, s. 270; Ankaravî, Mesnevî Şerhi, c. 4, s. 314.

134 Mevlânâ, Mesnevî, c. 4, b.n: 1045-1048.

135 Konuk, Mesnevî- $i$ Şerîf Şerhi, c. 8, s. 435; Ankaravî, Mesnevî Şerhi, c. 4, s. 749-750.

136 Mevlânâ, Mesnevî, c. 4, b.n: 3255-3258.
} 
Mevlânâ, Hakk'a âşık olan çobanın otağının, sûret âleminden geçip mânâ âlemi üzerinde kurulduğunu ve bu otağın bekçisinin de hayvânî ruh olduğunu belirtmiştir. Âşık olanın hayvânî ruhu, aşkın ve âşı̆̆ın hükmüne tabi olur. ${ }^{137}$ Âşık olmayanlar ancak o çobanın otağının önündeki köpek gibidir. Çünkü aşkı tadan ile onu işiten aynı değildir. ${ }^{138}$

\begin{abstract}
"Hani o çoban gibi. O da ya Rabbi, seni arayan çobana gel. Gel de gömleğindeki bitleri ayıklayayım, kırayım. Çarı̆̆ımı dikeyim, eteğini öpeyim diyordu ya. Kimse aşk ve muhabbette ona eş olamazdı, fakat Tanr'yı tesbih etmeyi, ona söz söylemeyi bilmiyordu. Onun aşkı, gökyüzüne çadır kurmuştu. Köpeğe benzeyen can, o çobanın önünde bir köpek kesilmişti. Tanrı aşkının denizi coşunca onun gönlüne vurdu, senin kulağına değdi."139
\end{abstract}

\title{
13. Ruh Beden Farklılığı
}

İnsan ruh ve bedenden oluşan bir varlıktır. Bu birliktelik ruhun bedene veya bedenin ruha benzediği anlamına gelmez. Aslolan insanın ruhudur. Ruh, beden kalıbında olmakla birlikte beden ruh gibi mânevî özellikleri taşımaz, arslanla ava giden kurt ve tilkinin arslan olamayacağ gibi. ${ }^{140}$ Mevlânâ hazretleri, ruh ve beden farklılığına vurgu yaparken köpeği bedene benzetmiş, bedenin ne kadar ruhla beraber olsa da ruha dönüşemeyeceğini ifade etmiştir.

"Terazide arpa, altınla arkadaş olmuştur. Fakat bununla arpanın da altın gibi kıymetlenmesi icap etmez. Ruh, şimdilik kalıba yoldaş olmuştur. (kalıp, rûhu korumaktır). Nitekim köpek de bir zaman için kapıyı korur."141

Arpadan murâd sâlikler, altından murâd ise insân-1 kâmillerdir, kâmilin yolda olana refâkatinin nice hikmetleri vardır. Hayvânî nefs köpek tabiatında olmakla birlikte rûh, emir âleminden yüce bir mertebedendir. İkisinin birbirlerine yakınlığı olmakla birlikte insanı kıymetli kılan rûhudur. ${ }^{142}$ Ashâb-1 Kehf'in kapısında da köpek bir müddet bulunmuştur. Ama bu durum köpeğin Ashâb-1 Kehf mertebesinde olduğunu göstermez. ${ }^{143}$

\section{Düşünmek / Akletmek}

Mevlânâ, akl-1 selîm sahibi olmanın önemini vurgulamış ve böyle bir akla sahip olan kişinin yanlış yapmayacağına işâret etmiş, bir iş/olay karşısında acele karar veren kişiyi, yemeğini koklamadan hemen saldırıp yiyen köpeğe benzetmiştir. ${ }^{144}$

\footnotetext{
137 Konuk, Mesnevî-i Şerîf Şerhi, c. 10, s. 376.

138 Ankaravî, Mesnevî Serhi, c. 5, s. 712-713.

${ }^{139}$ Mevlânâ, Mesnevî, c. 5, b.n: 3320-3324.

140 Tâhiru'l-Mevlevî, Mesnevî Şerhi, c. 3, s. 1415.

${ }^{141}$ Mevlânâ, Mesnevî, c. 1, b.n: 3019-3020.

142 Konuk, Mesnevî-i Serîf Şerhi, c. 2, s. 311-312.

143 Ankaravî, Mesnevî Şerhi, c. 1, s. 564; Sarı Abdullah Efendi, Cevâhir-i Bevâhir-i Mesnevî, c. 4 , s. 192.

${ }^{144}$ Konuk, Mesnevî-i Şerîf Şerhi, c. 6, s. 287; Ankaravî, Mesnevî Şerhi, c. 3, s. 578.
}

Turkish Academic Research Review - Türk Akademik Araştırmalar Dergisi 
“Çünkü şüphe yok, yavaş iş Rahman'dandır. Acele ediş ise melûn Şeytan'dan. Önüne bir lokma atsan köpek bile köpekliğiyle önce koklar da sonra yer a ihtiyatlı adam! O burnuyla koklar, biz aklımızla koklarız. Hele bir bak, demek ki biz de her şeyi inceleyen aklımızla kokluyoruz." 145

\title{
15. Allah'a İtaat
}

Hz. Mevlânâ, aşağıdaki beyitlerde Türkmen çadırının önündeki köpeklerin yedikleri birkaç lokmanın teşekkürü olarak efendilerine sâdık olduklarını, bu sadâkatin gereği olarak obaya yaklaşan efendilerinin yabancısı olanlara saldırdıklarını, dostu olanlara ise dostluğun nişânesi olarak kuyruk salladıklarını belirtmiş, köpeğin efendisine sadâkatinden hareketle kulun, iman ettiği Hak Teâlâ'nın sonsuz kudreti karşısında acziyetini ve O'na muhtaçlığını ortaya koymuştur. Hz. Mevlânâ, kulun Hakk'a bağlılıkta köpekten daha aşağı olamayacağını ve Hak Teâlâ'nın kendisine iman edenlere mükâfâtı çok çok vereceğini belirtmiştir. ${ }^{146}$

\begin{abstract}
"Benim tabiatım da değişmedi, unsurum da. Ben Allah kılıcıyım, izinle keserim. Türkmenin köpekleri, çadır kapısında misafire yaltaklanmış, ama çadır yanına yabancı biri uğrayacak olursa köpeklerden aslancasına hamleler görür. Kullukta, ben köpekten aşağ değilim; Allah da hayat ve kudrette bir Türkten aşağı kalmaz.”147
\end{abstract}

\section{Mevlâ'yı Aramak}

Mevlânâ, aşağıdaki beyitlerde yaşadıkları devirde Hak dini temsil eden Ashâb-1 Kehf'in köpeğinden bahisle, köpeğin Allah'1 isteyen tarafta olduğunu belirtmiştir. İnsan vücudu her an kendisinde şeytan, melek veya nefsin havâtırlarının cevelân ettiği bir orman gibidir. Bu ormanın, insân-1 kâmili temsil eden aslanı ise bâtını îmâr eder. Mevlânâ, âriflerin bâtınındaki güzelliklerden faydalanmada Ashâb1 Kehf'in köpeğinden daha aşağıda olmama hususunda uyarıda bulunarak, insana ruh nimetinin kıymetini bilmesini tembihlemiştir. ${ }^{148}$

\begin{abstract}
“Ashab-1 Kehf'in köpeğine onlardan öyle bir huy sirayet etti ki sonunda Allah'1 aramaya koyuldu. Kalpte her an bir çeşit şey baş gösterir. İnsan bazen şeytanlaşır, bazen melekleşir. Bazen tuzak kesilir, bazen yırtıcı hayvan! Aslanların bildiği o acayip ormandan, gönüller tuzağına gizli bir yolu bulunan o meşelikten, içten içe hırsızlık et, can mercanını çal! Ey köpekten aşă̆ı, ariflerin gönüllerinden o mercanı elde et.! Mademki hırsızlık ediyorsun, bari
\end{abstract}

145 Mevlânâ, Mesnevî, c. 3, b.n: 3497-3499.

146 Tâhiru'l-Mevlevî, Mesnevî Şerhi, c. 1, s. 485-486; Konuk, Mesnevî̀i Şerîf Şerhi, c. 1, s. 282; Ankaravî, Mesnevî Şerhi, c. 1, s. 198; Sarı Abdullah Efendi, Cevâhir-i Bevâhir-i Mesnevî, c. 1, s. 501.

147 Mevlânâ, Mesnevî, c. 1, b.n: 830-833.

148 Konuk, Mesnevî-i Şerîf Şerhi, c. 3, s. 398-399. 
lâtif inciyi çal! Mademki hamallık ediyorsun, bari yüce bir yük

yüklen!"'149

\section{Sirra Mazhar Olmak}

Mevlânâ aşağıdaki beyitlerinde köpeğe olumlu anlam yüklemiş ve Hakk’a ulaşmış olan kişileri köpek postuna bürünmüş, adı, sanı olmayan kişilere benzetmiştir.

"Nice köpek postuna bürünmüş adsız sansız kişiler var ki perde ardında şarapsız kalmazlar. Oğul, bu şarap, için can ver. Savaşsız, sabırsız yenme olur mu hiç?"150

Köpek postundan murad, mahviyyet sahibi görünüşte hakir ve zelil olan kişilerdir. Kadehten murad, mârifet ve ilâhî muhabbet şarabıdır. Köpek postu aynı zamanda dünya ehlinin elbisesini temsil eder, bu elbiseyi ârifler giyer, dünya ehli bu ârifleri tanıyamaz. ${ }^{151}$

\section{Vefâ}

Hz. Mevlânâ, nîmet verene karşı köpeğin büyük bir bağlılık içinde olduğundan hareketle, sonsuz nîmetler bahşeden Hak Teâlâ karşısında kulluğun önemini, şükrün ve sadâkatin ne yüce bir sıfat olduğunu şöyle belirtmiştir: ${ }^{152}$

“Allah Seba'lılara pek büyük bir genişlik ve rahatlık verdi, yüz binlerce köşk, hayvan ve bağ ihsan etti. O kötü yaradılışlı adamlar buna şükretmediler. Vefada köpekten de aşağı oldular. ${ }^{153}$ Köpeğe bir kapıdan bir lokma ekmek verilse o kapıya bağlanır, hizmetkâr olur. Kapıya bekçi kesilir. Ona eziyet edilse yiyeceği lâyıkıyla verilmese bile o kapıyı bırakmaz. Orada karar eder, başka bir kapıya gitmez. Oraya bir garip köpek gelse oradaki köpekler, onu gece gündüz tedip ederler. İlk konağına git. Oradan nimetlendin, o nimetin hakk1, gönlünü oraya rehin etmendir derler. Yerine git, o nimetin hakkını bundan fazla terketme diye onu isırırlar. Sen de gönül ve gönül ehlinin kapısından bir hayli âb-ı hayat içtin, gözlerin açıldı. Canın, ehlin diller gönlünden nice şükür, vecit ve kendinden geçiş gıdaları yedi." "154

\section{Assk / Hak Âșı̆ı}

\footnotetext{
149 Mevlânâ, Mesnevî, c. 2, b.n: 1425-1429.

150 Mevlânâ, Mesnevî, c. 3, b.n: 210-211.

${ }^{151}$ Konuk, Mesnevî̀-i Şerîf Şerhi, c. 5, s. 73; Ankaravî, Mesnevî Şerhi, c. 3, s. 52.

152 Konuk, Mesnevî-i Şerîf Şerhi, c. 5, s. 91; Ankaravî, Mesnevî Şerhi, c. 3, s. 63.

${ }^{153}$ Bu husus Kur'ân-1 Kerîm'de A râf sûresinin 179. âyetinde şöyle belirtilmiştir: "Andolsun biz, cinlerden ve insanlardan birçoğunu cehennem için yaratmış olduk. Bunların kalpleri vardır ama onlarla kavrayamazlar; gözleri vardır ama onlarla göremezler, kulaklarl vardır ama onlarla işitemezler. Onlar hayvanlar gibidir, hatta daha da şaşkındırlar. İște asıl gafiller onlardir."

154 Mevlânâ, Mesnevî, c. 3, b.n: 285-294; Aynı konu çerçevesinde benzer beyitler için bk. Mevlânâ, Mesnevî, c. 3, b.n: 310-324.
}

Turkish Academic Research Review - Türk Akademik Araştırmalar Dergisi 
Hz. Mevlânâ, Leylâ'nın mahallesindeki köpeğe Mecnûn'un baktığı gibi bakamayanların sûrette kaldıklarını ve sûretin arkasındaki hakîkati göremediklerini, onda esmâ-i ilâhiyyenin saklı olduğunu, Leylâ'nın şahsında köpeğin aşk1 temsil ettiğini şöyle belirtmiştir: ${ }^{155}$

“Tıpkı Mecnun gibi. O da bir köpeği okşamakta, öpmekte, önünde yanıp erimekteydi. Etrafında eğilip bükülerek onu ululayıp ağırlayarak dönüp dolaşıyor, ona sâf şeker şerbeti veriyordu. Bir herzevekil dedi: "Ey ham mecnun, bu yapıp durduğun şey ne delilik ne sersemlik, köpeğin ağzı daima pis şeyleri yer. Ardını bile diliyle temizler." Köpeğin ayılarını bir hayli saydı döktü. Zaten ayıp gören gayb âleminin kokusunu bile alamaz. Mecnun dedi ki. "Sen, baştan başa suretten, cisimden ibaretsin. Gel de benim gözümle bir bak! Bu köpek, bence Allah'ın bir çözülmez tılsımıdır. Bu köpek, Leylâ'nın mahallesinin bekçisi. Himmetine bak, gönlüne, canına, irfanına dikkat et ki neresini seçmiş, neresini yurt edinmiş? O benim mağaramın yüzü kutlu köpeği, hattâ o benim dertdaşım, gamdaşım. Onun mahallesinde yurt tutan köpeğin ayağının bastığı toprak bile ulu aslanlardan yeğdir. Ey köpeklerine aslanların köle olduğu sevgili, anlatmaya imkân yok ki, sus vesselâm!” Dostlar, suretten geçerseniz her yer sizin için cennettir. Gül bahçesi içinde gül bahçesidir. Suretini kırdın, yaktın mı her şeyin suretini kırdın demektir."156

Bu beyitlerde geçen Leylâ insân-1 kâmil, köpek fakîrler, aslanlar ise zâhir ulemâsı şeklinde de yorumlanmıştır. ${ }^{157}$ Ayrıca Mecnûn kendini Ashab-1 Kehf'e, o köpeği de onların köpeği olan Kıtmir'e teşbih etmiştir. ${ }^{158}$

Mevlânâ, Hak âşı̆̆ını köpeğe benzeterek, aşka ulaşmak için çaba sarfetmenin gereğini şöyle belirtmiştir:

"O dertli definenin kâğıdını padişah, o dertlere uğramış fakire verince;

Yoksul adam, düşmanlarından, onların saçmasından emin oldu, gidip sevdalandığı şeye adamakıllı sarıldı. İnsanı dertlere düşüren aşka yâr oldu. Köpek, yarasını yalaya yalaya iyi eder."159

“Böyle bir misal Hak âşığının şanını küçültmez. Belki Hak âşığını köpeğe benzetmek, onu yükseltir. Aslolan sûret değil, mânâdır. Çünkü Peygamber Efendimiz bir hadislerinde "Köpek gibi yaşayan kimse en iyi, en mükemmel bir

\footnotetext{
${ }^{155}$ Konuk, Mesnevî̀-i Şerîf Şerhi, c. 5, s. 164-165.

156 Mevlânâ, Mesnevî, c. 3, b.n: 567-574.

${ }^{157}$ Konuk, Mesnevî-i Şerîf Şerhi, c. 5, s. 164-165.

158 Tâhiru'l-Mevlevî, Mesnevî Serhi, c. 5, kitap 2, s. 151.

159 Mevlânâ, Mesnevî, c. 6, b.n: 1975-1977.
} 
yaşayış tarzı seçmiş gibidir" diye buyurmuştur. ${ }^{160}$ Burada köpekle ilgili on mânâ vardır: "Malı yoktur. Halâyık arasında kadir ve i’tibârı yoktur. Yeryüzünün her tarafi kendisine döşektir. Vaktinin çoğu açlık ile geçer. Eğer efendisi dövse darılıp kapısını terketmez. Düşmana hücum eder, dosta taarruz etmez. Gece ve gündüz efendisinin kapısını muhâfaza eder, hiç uyumaz. Amelinin çoğu sükûttur. Efendisi az olsun çok olsun her ne verirse râzı olur. Öldüğü vakit mîrâs bırakmaz. Hak Teâlâ sâliklerinin ahlâkı ise Hakk’a karşı böyle olmak lâzımdır."161

\title{
20. Alah Dostu
}

Mevlânâ hazretleri, kişinin nefse hoş gelen şeylerden yüz çevirerek Ashâb-1 Kehf'in mağarasındaki köpeğe teşbîhle Allah dostu olup nefsânî isteklerden kurtulabileceğini şöyle ifade etmiştir.

\begin{abstract}
"Tanrı sanatlarını gören gözler olmasaydı ne gökyüzü dönerdi ne yeryüzü gülerdi. "Sen olmasaydın” sözü, keskin ve görür gözler içindir. Fakat halk, kadın ve yemek aşkından nereden Allah sanatına bakacak, nereden Allah aşkına düşecek? Yiyecek birkaç köpek olmadıktan sonra tutmaç suyunu köpeklerin yiyecekleri yere dökmezsin ki. Yürü, Allah mağarasının köpeği ol da o, seni seçsin, bu yal yerinden kurtarsin."162
\end{abstract}

Mağara kesâfet ve cismâniyet âlemini, yal yeri dünyevî ve bedenî zevkleri temsil eder. Cismâniyet ve kesâfet âlemi, Hakk'ın esmâ ve sıfatlarının mazharı olan mağara gibi karanlıktır. İnsan ruhu bu mağarada hapistedir. Sâlik olan kişi, Hakk'ın mutasarrıf olduğu bu mağaranın köpeği olursa, Ashâb-1 Kehf’in köpeği gibi köpeklikten kurtulup hakîki insanlığa ulaşabilir, Hakk'ın huzuruna çıkabilir. ${ }^{163}$

\section{Sonuç}

Mevlânâ, Mesnevî’ sinde köpek karakterini hem olumlu hem de olumsuz anlamda metaforik bir üslupla kullanmıştır. Mesnevî̀ de, bâtıl inanca sahip, zâlim, dünyaya düşkün, nefsin esiri olan, kötü ahlâka sahip, dünyada yemek için yaşayıp mânâ kapısını çalamayacak olan, bedenin hükmü altına giren, âriflerin ulaştıkları mânevî hakîkatlerden bîhaber olan, Allah dostlarının çağrılarına karşı cehâlet sergileyen, kendilerine ayna olan mânevîyat erlerine düşmanlık eden, Hakk'ın hitâbına sağır kesilen, küfrün sesiyle hakîkatin sesini bastırmaya çalışan, dünya malı ve makāmına sahip olmakla Allah'a muhtaçlığını unutan, hidâyet ehline saldırmak için şeytan tarafından eğitilip kâfirlik yapan, Firavun gibi Tanrılık iddiasında bulunarak insanları kandırmak için münâfıklık yapan, mânevî hakîkatler peşinde koşuyor gözüküp lokma peşinde koşarak dervişlik taslayan, hakîkatten habersiz kalıp hayâdan nasibini almayan, zor zamanda Allah'a güvenip kolay zamanda tevekkülü terkeden, aklı başından gidip öfkelenen, aşktan yoksun olmakla ancak

${ }^{160}$ Konuk, Mesnevî-i Şerîf Şerhi, c. 12, s. 21-22; Tâhiru'l-Mevlevî, Mesnevî Şerhi, c. 10, s. 241-242.

${ }^{161}$ Konuk, Mesnevî-i Şerîf Şerhi, c. 12, s. 22.

162 Mevlânâ, Mesnevî, c. 6, b.n: 1660-1664.

${ }^{163}$ Konuk, Mesnevî-i Şerîf Şerhi, c. 11, s. 542-543; Ankaravî, Mesnevî Şerhi, c. 6/1, s. 402.

Turkish Academic Research Review - Türk Akademik Araştırmalar Dergisi 
âşığın kapısında köle olan, ruh ve beden karşılaştırmasında bedeni temsil eden, müteşeyyih olup mânevîyat yolunun harâmisi olan kişiler ve şeytan köpek metaforu ile anlatılarak, insanın kaçınması gereken tutum ve davranışlara dikkat çekilmiştir.

Mesnevî’de, köpek metaforu ile insana dair güzel hasletler, efendileri tarafından beslenip onlara itaat eden köpeklerin durumu ile Allah'a kulluk edenlerin durumu arasında benzerlik kurularak Hakk'ın mü'minlere verdiği mükâfâta nâil olan, Ashâb-1 Kehf'in köpeğinin hakîkat erleri ile birlikteliğinden hareketle Hak arayışında olan, sırra ermekle köpek postuna bürünen, köpeğin kendisine nimet verene sadâkatinden hareketle Allah'ın sonsuz nimetleri karşısında O'na vefâlı olan, Leylâ'nın köpeğinden hareketle cisme takılmayıp görüntünün arkasındaki aşkı gören, köpeğin güzel hasletlerine sahip olmakla Hakk'a âşık olan, nefse hoş gelen şeylerden yüz çevirip Allah dostu olan kişiler şeklinde ele alınmıştır.

Mevlânâ, anlatılarında yer verdiği köpek metaforunda belirli bir kalıbı kullanmamıştır. Yerine göre insana ait olumlu veya olumsuz özellikleri köpek metaforu üzerinden aktarmıştır. Burada Mevlânâ'nın kullandığı incelikli dili anlamada konunun bağlamının önemi ön plana çıkmaktadır. Mevlânâ'nın Mesnevî̀ de kullandığı köpek ve diğer hayvan metaforları, dinî hakîkatlerin her yaştan insana ulaşmasını sağlayacak bir içeriğe sahiptir.

Köpek metaforunda insana ait daha çok kötü yönler resmedilmiştir. Mevlânâ, Mesnevî’sinde insanın kendine dair düzeltmesi gereken olumsuzluklarla ilgili hikâye dilinin tesirini kullanarak, muhatabın savunma mekanizmasını devreye sokmadan farkındalık sağlamaya çalışmıştır. Kullanılan metaforlar, insanın kendi hatasını, günahını veya zayıf noktasını daha kolay farketmesini sağlayacak bir içeriğe sahiptir. Bu açıdan bakıldığında Mevlânâ, insan fitratını iyi tahlil ederek hayatın içinden mesajları metaforlar yolu ile insanlara ulaştırmış ve halkın dinî hakîkatleri daha kolay idrâk etmesini sağlamak istemiş ve insanın değişimimde negatif direnç göstermemesine vesîle olacak bir yöntem kullanmıştır. Pek çok toplumda kullanılan ve insan var oldukça da devam edecek olan hikâye ile hakîkatin aktarımı yöntemini başarılı bir şekilde kullanan Mevlânâ, köpek metaforu ile aslında insanın en önemli ve öncelikli düşmanları olan nefs ve şeytan konularına ve bu iki konu ile bağlantılı yan konulara temas etmiştir.

Kaynakça

Aclûnî, İsmâil b. Muhammed, Keşfü'l-Hafâ ve Müzîlü'l-İlbâs, thk. Abdülhamîd b. Ahmed b. Yusuf b. Hindâvî, El-Mektebetü'l-Asriyye, b.y. 1420 / 2000 .

Ankaravî, İsmâîl Rusûhî, Mecmûatü'l-Letâif ve Ma'mûretü'l-Maârif Mesnevî Şerhi, Matbaa-i Âmire Yayınları, İstanbul 1289.

Atay, Rıfat, "Dinsel Çoğulculuk Açısından Farklı Mevlâna Okumaları: Bir Çözümleme Denemesi," Harran Ü. Ilahiyat Fakültesi Dergisi 16 (Temmuz-Aralık 2006).

Atay, Rıfat, “Mevlana'nın Hiristiyanları, Hıristiyanların Mevlana'sı: Mesnevi Merkezli Çoğulcu Bir Okuma Denemesi," Mevlana Mesnevi ve Mevlevihaneler Sempozyumu Bildirileri (30 Eylül-01 Ekim 2006), Manisa 2007.

Atay, Rifat, "Bilgi ve Bilgi ve Eylem Arasında Mevlana'da Estetik Değerler Eğitimi: Mesnevi Merkezli Bir Okuma Denemesi” Eğitimde Gelecek Arayışlart Dünden Bugüne Türkiye'de Beceri Ahlak ve Değerler Ĕgitimi, Arzu Güvenç Saygın, Murat Saygın, Ed., Ankara: Atatürk Araştırma Merkezi Yayınları, 2016.

Baykal, Özgün, “Mevlânâ'nın Mesnevî’sinde Hayvan Hikâye ve Motifleri”, Şarkiyat Mecmuası, İstanbul Üniversitesi Edebiyat Fakültesi Şarkiyat Enstitüsü, İstanbul Edebiyat Fakültesi Basımevi, V/1964. 
Buhârî, Muhammed b. İsmâîl, El-Edebü'l-Müfred, thk. Semîr b. Emîn ezZührî, Mektebetü'l-Maârif, Riyad 1998.

........, El-Câmiu'l-Muhtasar (Sahîhu'l-Buhârî), thk. Muhammed Züheyr b. Nâsri'n-Nâsır, Dâru't-Tavki'n-Necât, b.y., 1422.

Ceyhan, Semih, "Ubûdiyyet", TDV İslâm Ansiklopedisi, https://islamansiklopedisi.org.tr/ubudiyyet (31.10.2020).

Çiçek, Hasan, “Mevlana'nın Mesnevi'sinde Soyut Kavramların İfade Aracı Olarak Metafor”, Yüzüncü Yıl Üniversitesi Sosyal Bilimler Enstitüsü Dergisi, 22 / 2012.

Doğan, Mehmet, Büyük Türkçe Sözlük, İz Yayıncılık, İstanbul, 1996.

Keklik, Nihat, "Mevlânâ'da Metafor Yoluyla Felsefe", 1. Millî Mevlânâ Kongresi (Tebliğler), Selçuk Üniversitesi Basımevi, Konya 1986.

Konuk, Ahmed Avni, Mevlânâ Celâleddîn-i Rûmî Mesnevî̀-i Şerif Şerhi, haz. Komisyon, Kitabevi Yayınları, İstanbul 2009.

Mevlânâ Celâleddîn-i Rûmî, Mesnevî, Çev: Veled İzbudak, Millî Eğitim Bakanlığı Yayınları, İstanbul,1995.

............, Mesnevî-i Ma nevî, Mevlânâ, haz. Derya Örs, Hicâbi Kırlangıç,

Türkiye Yazma Eserler Kurumu Başkanlığı Yayınları, İstanbul 2015.

Müslim b. El-Haccâc Ebu'l-Hasan el-Kuşeyri'n-Nîsâbûrî, El-Müsnedü'lSahihu'l-Muhtasar, thk. Muhammed Fuâd Abdülbâkî, (Daru İhyâi't-Türâsi'l-Arabî, Beyrut, t.y.)

Niyâzî-i Misrî, Niyâzî-i Mısrî Dîvânı, haz. Kenan Erdoğan, Akçağ Yayınları, Ankara 1998.

Ögke, Ahmet, Vâhib-i Ümmî'den Niyâzî-i Mısrî̀ye Türk Tasavvuf Düşüncesinde Metaforik Anlatım, Ahenk Yayınları, Van 2005.

Özköse, Kadir, "Mevlânâ'nın Öğretilerinde Kulluk Bilinci”, Somuncu Baba Aylık Ilim Kültür ve Edebiyat Dergisi, 21 (170) / 2014.

Öztürk, Abdullah, "Hayvan Hikayelerinin Yorumunda, Hz. Mevlana'y1 Batılı Fabl Yazarlarından Ayıran Özellikler”, T.C. Celal Bayar Üniversitesi Manisa Yöresi Türk Tarihi ve Kültürünü Araştırma ve Uygulama Merkezi Birinci Uluslararası Mevlânâ, Mesnevî ve Mevlevîhâneler Sempozyumu Bildirileri, Manisa 2002.

Sarı Abdullah Efendi, Cevâhir-i Bevâhir-i Mesnevî, İstanbul 1287-1288.

Senâyî Hasan Şabânî, Dîvân-ı Illâhiyât, haz. Mustafa Tatcı, H Yayınları, İstanbul 2013.

Şahin, Mehmet, Bâkî Dîvânı'nda Ayna Metaforu, Journal of Social, Humanities and Administrative Sciences, 6 (25):519-534.

Şahin, Mehmet, Etvâr-1 Seb‘a Geleneği ve Vâhib Ümmî’de Etvâr-1 Seb‘a,

$\begin{array}{lllll}\text { Turkish Studies } \quad-\quad \text { Religion, } & 2020, & 15(1), & 77-96 .\end{array}$

https://dx.doi.org/10.29228/TurkishStudies.40030, s. 77-96.

Tâhiru'l-Mevlevî, Mesnevî Şerhi, Şamil Yayınevi, İstanbul 2014.

Tirmizî, Muhammed b. Îsâ b. Mûsâ b. ed-Dahhâk, Sünenü’t-Tirmizî, thk. Ahmed Muhammed Şâkir, Muhammed Fuâd Abdülbâkî, İbrâhîm Atvah, Şirketü Mektebeh, Misır 1975.

Yazçiçek, Ramazan, "Metafizik Alanda Sörf ya da Mecaz ve Semboller Üzerinden Anlamlandırma: Bir Anlatım Yöntemi Olarak Metafor”, Milel ve Nihal, 9 (1) / 2012.

Yûnus Emre, Dîvân-ı Ilâhîyât, haz. Mustafa Tatc1, Kapı Yayınları, İstanbul 2011.

Turkish Academic Research Review - Türk Akademik Araştırmalar Dergisi 